\title{
Controversies in social-ecological systems: lessons from a major red tide crisis on Chiloe Island, Chile
}

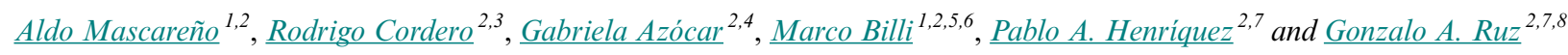

\begin{abstract}
Connecting the discussions on resilience and governance of social-ecological systems (SESs) with the sociological analysis of social controversies, we explore a major red tide crisis on Chiloe Island, southern Chile, in 2016. Theoretically, we argue that controversies not only are methodological devices for the observation of the complex relations between nature and society in moments of crisis, but also are materially embedded in the SES dynamics and can work for or against systemic resilience. Empirically, we show that Chiloe's SES is an unstable regime prone to sudden shifts and identify the configuration of different lock-in mechanisms expressed in the reproduction of structural fragilities over the last three decades. From the examination of the social controversies on the 2016 red tide crisis, we draw several lessons. First, there is a complex interplay of visible and hidden fragilities of Chiloe's SES that, while being ignored or their resolution postponed to the future, materialize in the daily experience of inhabitants as a series of historical disappointments. Second, the unfolding of Chiloe's social-ecological crises involves epistemic disputes not only over concrete events but also on the very construction of the SES as a social-natural reality. In turn, this creates conditions for the emergence of strategic alignments between local, national, and transnational actors and shows the extent to which the socio-political articulation of knowledge may contribute to either improve or block the governance of the SES. Third, the social resources that came to light with the controversies reveal pathways for improving the governance regime of Chiloe Island's SES. This dimension highlights the normative relevance of commitments to recognize multiple scales of knowledge and articulate a plurality of actors in a nonhierarchical logic of cooperation.
\end{abstract}

Key Words: Chiloe Island; controversy; governance; regime shift; resilience; salmon aquaculture

\section{INTRODUCTION}

The social-ecological systems (SESs) approach has become an established field of research in the last decades. Drawing on the assumption that human affairs and natural events interpenetrate each other and are embedded in the biosphere (Folke et al. 2016), the approach has developed interesting building blocks for the interdisciplinary study of SESs. Taking the concept of resilience as a fundamental analytical and action-oriented tool as well, SES theory offers a detailed view as to how SESs navigate in a dynamic environment absorbing disturbances by learning and adapting to complex social-ecological conditions, on the one hand, and by dealing with uncertainty and nonlinear dynamics through the flexible governance of people, communities, and societies, on the other (Folke et al. 2010, Folke 2016).

As a property of complex systems, however, resilience is also exposed to the pressures of complexity. Paradoxically, being adapted to a complex environment may lead to decreasing levels of the system's adaptability. This is the case when the system persists into a mode of behavior that increases its robustness by preserving some features in spite of changes in a dynamic landscape. This self-stabilizing feedback is referred to as a lockin mechanism, or as a trap to emphasize negative connotations (Scheffer and Westley 2007). In so doing, the system develops hidden fragilities, which "are typically only revealed through failure" (Anderies et al. 2013), the most extreme of them being the case of a regime shift or critical transition, namely, "the transitions in which a positive feedback pushes a runaway change to a contrasting state once a threshold is passed" (Scheffer
2009:104). In other words, slowly emergent, rather hidden dynamics may "ultimately trigger sudden crisis and surprise" (Holling et al. 2002:9).

We aim to contribute to SES theory from a sociological point of view by exploring a major red tide crisis on Chiloe Island, southern Chile, in 2016. Briefly, the Chiloe red tide crisis can be described as a tightly coupled sequence of sudden developments in which natural and social events correlate with each other in an integrated fashion. The social-ecological crisis began with an algal bloom (Pseudochattonella verruculosa) killing salmon (Atlantic salmon, Salmo salar; Coho salmon, Oncorhynchus kisutch) in aquaculture and and was followed by a second algal bloom (Alexandrium catenella) triggering a major stranding of shellfish. The depth and geographic extension of the crisis and the uncertainty regarding the causes led to strong controversies among actors placed at different societal scales, i.e., scientists, nongovernmental organizations (NGOs), sea and inland workers, and political authorities. Shortly thereafter, massive demonstrations took over the island and ended up in negotiations with the government. Drawing on this case, we argue that by analyzing the content and dynamics of these controversies, a clear picture of the entanglement of natural and social events arises that contributes to understanding the strengths and weaknesses in resilience of Chiloe Island's SES and to identifying windows of opportunity for governance in coastal communities.

Accordingly, our hypotheses are that (1) the Chiloe Island's SES is an unstable regime with inherent fragilities and (2) social controversies triggered during the crisis reveal a general

${ }^{1}$ School of Government, Universidad Adolfo Ibáñez, ${ }^{2}$ Research Centre Millennium Nucleus Models of Crises, ${ }^{3}$ Department of Sociology,

Universidad Diego Portales, ${ }^{4}$ Department of Social Work, Universidad Alberto Hurtado, ${ }^{5}$ Centre for Climate Science and Resilience, CR2, ${ }^{6}$ Earth System Governance Project, ${ }^{7}$ Faculty of Engineering and Sciences, Universidad Adolfo Ibáñez, ${ }^{8}$ Center of Applied Ecology and Sustainability (CAPES-UC), Santiago, Chile 
framework in which we can identify epistemic resources and networking capacities for improving the governance of Chiloe Island's SES. To combine micro- and macroperspectives on the controversies, this case study uses a range of methodologies, including content analysis of press articles and public documents, in-depth interviews, and network analysis of Twitter data.

First, we outline an analytical framework by linking the concepts of resilience, governance, and controversy. Second, we describe our research methods. Third, we introduce the case with background information. Fourth, we outline three key controversies in the Chiloe Island's red tide crisis and analyze its dynamics. Fifth, we discuss our findings in connection to the conceptual framework. Finally, we draw the lessons from the case.

\section{THEORY AND CONCEPTS}

Aligned with our main problem and hypotheses, relevant concepts to construct our case are resilience, governance, and controversy. The concept of resilience has a long-standing tradition in SES theory (Olsson et al. 2015, Folke 2016). As recently defined, it entails "the capacity to adapt or transform in the face of change in social-ecological systems, particularly unexpected change, in ways that continue to support human well-being" (Folke et al. 2016). Similar definitions emphasize learning, adaptation, selforganization, and coping capacities (e.g., Carpenter et al. 2001, Folke 2006, Walker et al. 2009, Folke et al. 2010, Anderies et al. 2013, Homer-Dixon et al. 2015).

Interestingly, in its original definition, Holling (1973) understands resilience by contrasting the term with stability. While stability refers to the rate of recovery of an SES to a state of equilibrium, resilience rather emphasizes the capacity of the system to absorb disturbances. Consequently, resilient SESs become characterized by change and adaptation (Holling and Gunderson 2002).

In a similar way, Holling et al. (2002) differentiate resilience, i.e., integrity of functions, from collapse, i.e., a functional dislocation. The fact that SESs change constantly absorbing disturbances does not mean that resilience is a property of infinite magnitude. On the contrary, beyond a given threshold the system may undergo a significant reorganization and flip to another basin of attraction (Holling 1973). This is called regime shift, catastrophic shift, or critical transition (Scheffer et al. 2001, Scheffer and Carpenter 2003, Folke et al. 2004, Folke 2006, Scheffer and Westley 2007, Scheffer 2009). Folke (2016) assumes that the relationship between resilience and regime shifts is central to SES theory: "As resilience declines, it takes progressively smaller disturbances to push the system into a different regime, or basin of attraction ... Such regime shifts are at the core of resilience thinking." In other words, the less resilient the SES, the more likely the regime shift. However, what explains losses of resilience? Increasing feedback loops may lead systems to the intensification of particular paths, to increase control when control does not work, and to intensify exploitation instead of exploring alternatives (Holling and Meffe 1996, Folke 2016). This is called a lock-in mechanism, which is caused by a "self-reinforcing adherence to a mode of behaviour [that] tends to promote inertia, a lack of responsiveness to changes in the environment" (Scheffer 2009:245). In this case, fragilities at lower scales are hidden by too much robustness of upper scales, thereby weakening system's resilience: "Any time a system becomes well adapted to a particular set of drivers ... it entrains hidden fragilities" (Anderies et al. 2013). This is especially the case when decision making is not prospective but only reacts to crises (Anderies et al. 2006).

These conceptual definitions are relevant to our purposes because the 2016 red tide crisis on Chiloe Island can be understood as a sudden regime shift produced by a loss of resilience. The relevant question is whether the undesirable consequences produced by a loss of resilience of Chiloe's SES can be avoided, and what kind of mechanisms may contribute to manage locks and hidden fragilities before exceeding critical thresholds. As the literature suggests, adaptive governance mechanisms are crucial in this regard as they involve different levels of decision making aimed at finding a balance between centralized and decentralized steering of SESs (Folke et al. 2005). The concept develops from the more restricted notion of adaptive management (Walters 1997) to the more contemporary concepts of adaptive comanagement and adaptive governance. Adaptive governance includes a polycentric coordination of multiple stakeholders, a combination of local and scientific knowledge, social involvement and participation, and reliance on different network scales for identifying alternative pathways and forms of dealing with the complexity of SESs (Olsson at al. 2004, Folke et al. 2005, Hahn et al. 2006, Gelcich et al. 2010, Österblom and Folke 2013, Westley et al. 2013).

However, the effectiveness of governance mechanisms is tested when confronted with both the controversial character of socialecological crises and the uncertainty regarding the fragilities of SESs. Consistent with this view, SES theory may benefit from taking into account the analysis of social controversies in a more systematic manner. In the first place, a controversy is an act of translation in which "the identity of actors, the possibility of interaction and the margins of manoeuvre are negotiated and delimited" (Callon 1984:203). Assuming our point of departure that human affairs and natural events are embedded in the biosphere (Folke 2016, Folke et al. 2016), the analysis of socionatural controversies tells us about the displacements, transformations, power relations, and evaluations enacted by diverse agents in SESs, mainly scientists, authorities, and local actors. This is particularly relevant in crises of SESs where uncertainty is the prevailing feeling, for "public controversies increase the visibility of these uncertainties" (Callon et al. 2009:19). If crises trigger learning and knowledge production and allow for the design of new strategies for governing SESs (Folke et al. 2005), socio-natural controversies in crisis situations offer a methodological access point to these processes. As they put into question the taken-for-grantedness of the social-ecological order and the ways of governing it, they make visible the hidden fragilities of apparently robust modes of dealing with SESs (Anderies et al. 2013). In other words, socio-natural controversies open the black box of ready-made knowledge and move actors to clarify their stances, interests, and resources for action (Latour 1987, 2005).

However, socio-natural controversies are not only methodological devices. While exploring them, we can observe the interplay and mismatch among multiple scales of knowledge, from individuals to collectives, leading to social-ecological conflicts (Ahlborg and Nightingale 2012). We can also reconstruct the power relations among actors within an institutional framework (Bryant 1998) as well as their networking capacities in the political ecology of the 
SES. Controversies are, therefore, embedded in the SES dynamics and can work for or against systemic resilience.

\section{METHODS}

For the identification and analysis of controversies, we employed mixed methodologies organized into four methodological steps. We present these steps briefly; for a detailed description, see Appendix 1.

Press articles: identification of main actors and stances. First, we conducted a content analysis of press articles to identify the main actors involved in the controversy and outline its borders. These actors are as follows: scientists and technical agents; nongovernmental organizations; sea workers, including gatherers, fishers, and divers, and inland workers; political authorities; and the salmon industry. We considered news articles from three national electronic newspapers, La Tercera, Emol, and El Mostrador, and two regional electronic media, La Estrella de Chiloé and SoyChiloe, in the period from 1 February 2016 to 31 December 2016. We selected and analyzed a sample of 50 news articles containing information on topics related to the developments of the 2016 Chiloe red tide crisis.

Documents of relevant organizations: mapping of controversial discourses. Having identified the main stances of actors involved in the controversies, we proceeded to examine more closely their arguments concerning the origins and developments of the red tide crisis. For that purpose, we conducted a content analysis of public documents that relevant organizations produced during the controversy: 26 documents coming from 11 organizations were reviewed (see Table A1.1 in Appendix 1).

In-depth interviews: reconstruction of actors' experiences. We explored the experience of actors and their meaningful constructions on the controversial origins and developments of the Chiloe red tide crisis. Between January 2017 and April 2017, we conducted 31 in-depth interviews with key informants involved in the events. These interviews were electronically codified using Atlas.ti to organize the material and recognize regularities and discontinuities (see Table A1.2 in Appendix 1).

Semantic analysis of Twitter data. We complement our qualitative analysis on the controversies by analyzing semantic associations in Twitter databases before, during, and after the social-ecological crisis. We identified accounts of representative actors and organizations that played a key role during the process (see Table A1.3 in Appendix 1). Our final corpus has 5104 tweets (see Table A1.3) and was constructed from a set of $35 \mathrm{key}$ words containing the most relevant terms associated with the social-ecological crisis on Chiloe Island (see Table A1.4 in Appendix 1).

As a matter of crisis management, representatives of the salmon industry avoided public declarations during and after the crisis. One year after the events, most of them also rejected being interviewed for this research. Only two short interviews could be conducted with representatives of the salmon industry. For methodological reasons of contrastability, these sources were not considered in the analysis. In the Discussion, we take this selfexclusion from the public controversy as a valuable input for the configuration of the political ecology of Chiloe's SES, and we complement this with further information on the view of the salmon industry.

\section{BACKGROUND}

\section{Red tide causes}

Red tide events or harmful algal blooms have increased in number and intensity throughout the world in the last decades. Most general causes triggering red tides are related to climate change and global warming (Anderson 1994, Okaichi 2010, Glibert et al. 2014). Since the 1980 s, a more SES-oriented perspective paid attention to human impacts leading to coastal pollution, such as watershed management and the use of coastal waters for aquaculture (e.g., Anderson 1989, 2009). Wells et al. (2015) consider ballast waters and fouling of vessels as seeding and spreading mechanisms of harmful algal blooms. Heisler et al. (2008) highlight the scientific consensus around the relationship between harmful algal blooms and human-induced eutrophication of waters and the claim that management of nutrient inputs to the watershed will reduce algal blooms. More recently, Glibert et al. (2018) include atmospheric deposition of nitrogen as the most relevant agent of eutrophication and refer to Asia, western Europe, and North America as the most active regions in exporting loads of nutrients.

Since the turn of the 21 st century, studies on red tides include psychosocial assessments. Drawing on the concept of risk perception, Kuhar et al. (2009) argue that social impacts of red tides should be assessed in terms of not only factual consequences, i.e., illness, casualties, unemployment, and economic losses, but also observing their meaning for affected people, for they can amplify or attenuate the general evaluation of the situation. Similarly, Nierenberg et al. (2010) and Kirkpatrick et al. (2014) have shown the extent to which available sources of information, online or offline, may nurture misconceptions of red tides and narrow people's knowledge on local regulations and triggering factors. As a consequence, risk behaviors reproduce and amplify critical effects. In addition, studies on coastal communities used to red tides have shed light on the development of practical knowledge and collective-meaning structures for dealing with algal blooms (Kruke and Olsen 2012). No analyses of controversies around red tide events have been made so far.

\section{Red tides and aquaculture on Chiloe Island}

Chiloe Island is located between latitudes $41^{\circ} 4^{\prime}$ and $43^{\circ} 2^{\prime} \mathrm{S}$ in southern Chile (see Fig. 1). Until the 1970s, the island had been mainly a rural region, highly isolated from the mainland, with an agricultural economy and seasonality of artisanal fishing. In the 1980s, the island became the center of Chilean salmon aquaculture. Three periods can be distinguished in the national institutional framework regarding this industry: (1) socialecological silence in the 1980 s with rising investment and impacts; (2) the economic imperative of the 1990s, characterized by a tension between rising demand and criticism of the industry; and (3) sustainable globalization from the 2000s, which has included the search for best practices and alliances (Barton and Fløysand 2010). Despite strong setbacks in 1989 because of SRS (salmonid rickettsial septicemia) disease and in 2007 because of the ISA (infectious salmon anemia) virus, the industry reached $29 \%$ of world production in 2015 , only surpassed by Norway with $51 \%$ (Iizuka and Zanlungo 2016).

The quick growth of the salmon industry deeply changed Chiloe's SES. On the one hand, industrial aquaculture historically overloaded the coping capacity of the SES leading to reductions 
Fig. 1. Chiloe Island, Chile.

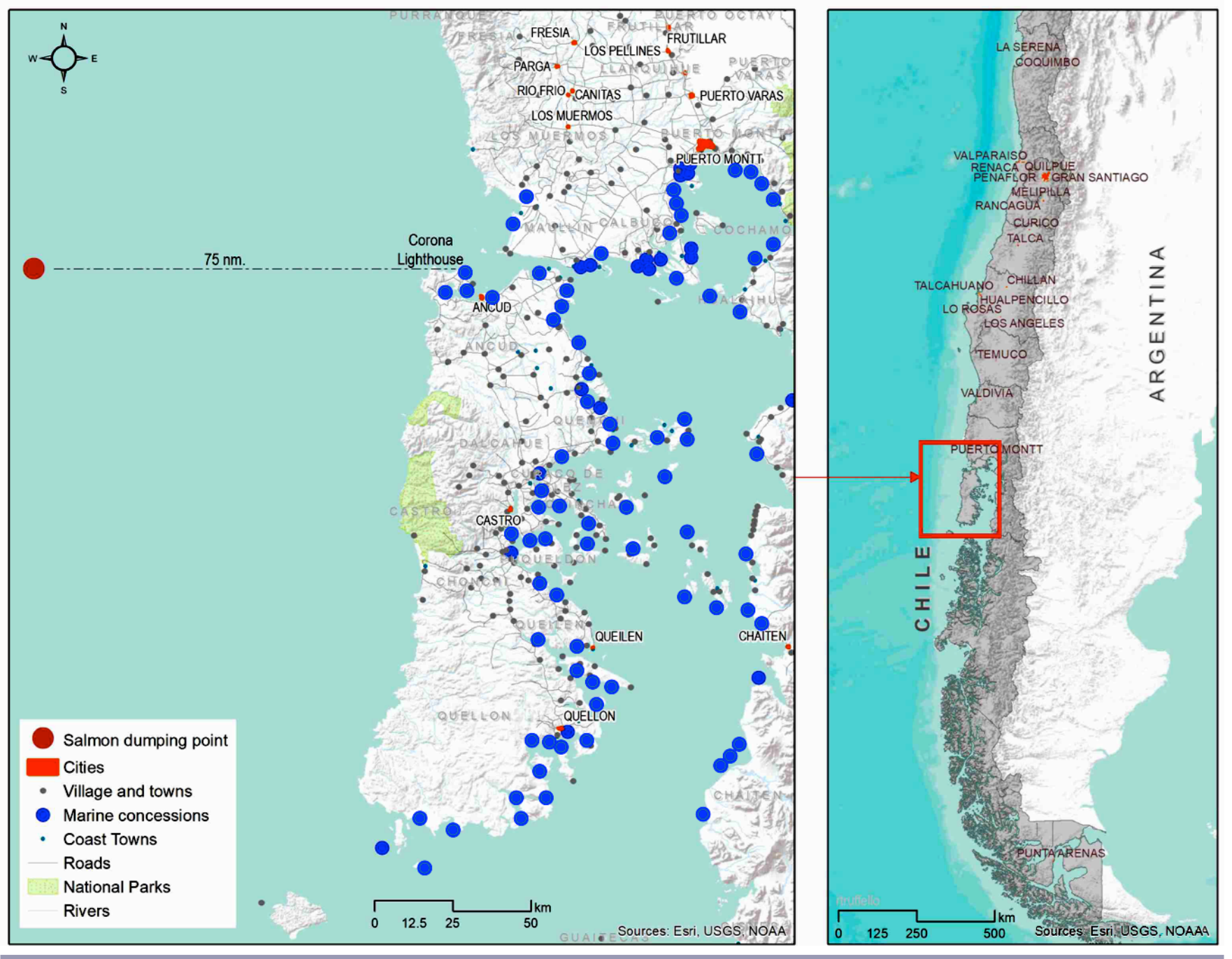

of biodiversity and to a strong dependence on the salmon industry (Tecklin 2016). On the other hand, the salmon industry created more than 17,000 new jobs contributing to the inclusion of women in the labor force and urbanization of the island, but also leading to processes of marketization of labor and culture (Barton and Román 2016).

In this area, the frequency of harmful algal blooms has become a great concern for the salmon industry, fishing communities, and authorities. Between 1972 and 2000, red tides connected mainly to two types of microalgae, Dinophysis acuta and Alexandrium catenella, moved from the extreme south (Magellan Strait, $56^{\circ} \mathrm{S}$ ) to northern regions (Aysen, $45^{\circ} \mathrm{S}$ ), producing 387 poisoning cases and 26 deaths over the period (Guzmán et al. 2002). Even if global warming and the El Niño current are known to be important factors in the increase of algal blooms in recent years (LeónMuñoz et al. 2018), research has shown a correlation among concentration of salmon farms, intense presence of nitrogen in seaweeds, and the outbreak of harmful algal blooms in Reloncavi Gulf, at latitude $41^{\circ} 7^{\prime} \mathrm{S}$. In this case, blooms take place in short- term pulses (Buschmann et al. 2006). Other studies have pointed to the intensive use of chemicals and density of farming as being responsible for the anthropogenic environmental degradation of the Chilean southern coast and the eutrophication of waters (Cabello and Godfrey 2016).

\section{The 2016 red tide crisis on Chiloe Island}

The red tide crisis on Chiloe developed from February to May 2016. The first algal bloom (Pseudochattonella verruculosa, which is not responsible for red tides but affects salmon) took place on February 2016. It brought about a mortality of 6,163,000 fish $(2700 \mathrm{t})$ in aquaculture within a week after it started (Servicio Nacional de Pesca y Acuicultura [Sernapesca] 2016a). By the second week of March 2016, mortality had significantly increased to $39,942 \mathrm{t}$ (Buschmann et al. 2016), with total losses for the industry ascending to 25 million fish. According to official figures, $57 \%$ of the dead fish was processed in reducing factories, and $30 \%$ was taken to local dump sites. The remaining 13\% (4600 t) was allowed to be dumped into the sea 75 nautical miles $(139.9 \mathrm{~km})$ off the northwest coast of Chiloe Island over a period of 16 days, 
Fig. 2. Controversies in the Chiloe red tide crisis.

TECHNICAL AGENCIES AND POLITICAL AUTHORITIES from 10 to 26 March 2016 (Sernapesca 2016b; see Fig. 1). As a consequence, $12 \%$ of the annual production of the salmon industry $(100,000 \mathrm{t})$ was lost during the first half of 2016, and 4500 workers, most of them inhabitants of Chiloe Island, were dismissed (González 2016).

Over the third week of March 2016, another algal bloom ( $A$. catenella) took place in the region. This microalga produces the biotoxin paralytic shellfish poison (PSP), attacking the nervous system of shellfish and affecting human health. This is known as red tide. On 19 March 2016, the Chilean Ministry of Health decreed a ban on fishing and shellfish extraction in Reloncavi Gulf. Most affected species were clams (Venus antiqua), scallops (Chlamys vitrea), oysters (Ostrea chilensis), blue mussels (Mytilus chilensis), Humboldt squid (Dosidicus gigas), seals (Otaria flavescens), and even sea birds. On 18 April, the ban was extended from Mansa Bay (latitude $40^{\circ} \mathrm{S}$ ) to the south of Chiloe Island (latitude $43^{\circ} \mathrm{S}$; Ministry of Health 2016), covering nearly 2000 $\mathrm{km}$ of coast. This was the first massive event of $A$. catenella in this zone of the Pacific Ocean. While the first bloom on February 2016 affected workers of the salmon industry, the second one on March and April 2016 seriously disrupted artisanal fishing, mainly because of the ban on fishing and shellfish extraction.

On 25 April 2016, a massive stranding of shellfish at Chiloe's seaside took place. About 6000 fishermen lost their livelihoods, and the entire population of Chiloe was severely constrained in terms of daily food supply. On 29 April 2016, the Chilean government declared Chiloe a "catastrophe zone," offering a US\$150 bonus to each affected family (Ministry of the Interior 2016). From 2 to 19 May 2016, massive demonstrations of Chiloe's inhabitants took over the main access ramp to the island with flaming barricades, producing a critical scarcity of food and fuel. Protests were originally directed against the government's measures, but also against the salmon industry for having contributed to the red tide when dumping the $4600 \mathrm{t}$ of rotting fish into the sea during the previous month. However, in addition to controversies and demonstrations surrounding the roots of the crisis, protests turned out to be a general expression of the accumulated disappointments inhabitants had against the state's historical neglect of the island's well-being.

\section{RESULTS AND ANALYSIS OF CONTROVERSIES}

We reconstruct the controversial process by which the red tide crisis on Chiloe emerges in the experience of the involved actors. The controversies began with the massive stranding of shellfish at the seaside on 25 April 2016, which led to a dispute on the origins of the red tide event and ended up with a controversy about the meaning of mobilizations. Technical agencies and political authorities, on the one side, and fishermen and social organizations, on the other, represented opposite parties in the dispute. Figure 2 summarizes the basic structure of controversies and the main controversial objects. For additional material from in-depth interviews and documents supporting the controversies, see Table A2.1 (first controversy), Table A2.2 (second controversy), and Table A2.3 (third controversy) in Appendix 2.

\section{First controversy: the truth of stranded shellfish}

Red tides are well known to fishermen, shellfish harvesters, and divers on Chiloe. Prior to the events of 2016, the island was declared a "catastrophe zone" by the government after an algal bloom in 2002. Similar events took place in 2006 and 2009. In addition, fishing trips to southern fjords, where red tides are even more common, have contributed to bringing fishermen, if not into direct contact with the experience of dealing with red tides, at least to acknowledge their significance. However, none of this accumulated experience was comparable to the stranding of shellfish at Chiloe's seaside on 25 April 2016. Overnight, more that $5 \mathrm{~km}$ of beach was covered with dead shellfish in one of the largest stranding points. Together with mounting evidence of the 
scale of the social-ecological disaster, fishermen's skepticism regarding the truth of official explanations, i.e., a red tide event triggered by global warming and a strong El Niño current, grew in equal measure. Fishermen were aware that the red tide was partly responsible for the stranding, but, as one of them said, this time "it comes with extras. And the authorities do not want to tell us the truth about what these extras are" ("Masiva varazón de machas genera preocupación en pescadores de Chiloé" 2016).

The fact were, in principle, hardly classifiable. In technical terms, a sudden regime shift had taken place. Red tides produce mortality, but $5 \mathrm{~km}$ of death overruns the limits of the expectable. What could explain the extra shellfish mortality this time? As scientists were likely to draw links with the toxin PSP as the basis to explain the stranding, a rural worker also described a "poisoning" of waters through chemicals coming from the salmon industry. However, the connotation of the concept was not natural but social-ecological: "You can't go to the beach because it's poisoned. It's as if you suddenly become blind and deaf ... This wasn't nature; it was on purpose" (interview with rural worker, fieldwork 2017).

For fishermen and inland workers, the poisoning of waters turned into an object of controversy. A month before the stranding on 19 March 2016, a ban on fishing and shellfish extraction had been decreed because of "high concentrations of the toxin known as paralytic shellfish poison" (Buschmann et al. 2016:4). At this point, fishermen, scientists, and the government agreed that the water was "poisoned" before the stranding, yet attributions regarding the poisoning were antithetical: Based on scientific reports, the government blamed global warming and the El Niño current for toxic algal blooms, whereas fishermen blamed the farming practices of the salmon industry. Insomuch as the event exceeded previous experience, it began to be framed by fishermen as "the most significant damage in history," "a crisis never seen before," and "a catastrophic mega-event" (interview with fishermen, fieldwork 2017). Fishermen's livelihoods were affected, workers of commerce suffered from scarcity of products, tourism declined, and inhabitants were deprived of basic ingredients for daily subsistence.

Three topics are relevant at this controversial moment: the questioning of truth regarding the causes of the stranding, the explanation of the factual poisoning of waters, and the need to identify responsibility for the social consequences of the disaster. The strong controversial dimension of the crisis emerges from the mismatch between actors' accumulated knowledge of the natural behavior of the sea, i.e., red tides, and the material evidence of the socio-natural disruption of inland life, i.e., unemployment, restriction of the means of livelihood, and scarcity. The socialecological crisis begins thus to take shape in the process of trying to make visible inland what had happened under the sea.

\section{Second controversy: the dumping of dead salmon}

The factual event of stranding of shellfish on 25 April 2016 acted as a critical threshold after which the highly controversial dimension of the crisis propagates in multiple directions. The factual event of the dumping of dead salmon into the sea, from 10 to 26 March 2016, belongs to the same category of unprecedented situations for most people on Chiloe. Almost $40,000 \mathrm{t}$ of salmon died within a few days. As a woman from a local organization describes:

\begin{abstract}
People know that the red tide comes from time to time, and know its consequences. But this [stranding of shellfish ] is something extraordinary; it is weird. It is due to the influence of salmon farmers dumping the salmons into the sea in a place other than the official one, nearer to us. (Interview, fieldwork 2017)
\end{abstract}

Considering this, the dumping is the node that connects an extraordinary present event (massive stranding) with extraordinary past actions (massive dumping), which reveals a holistic comprehension of the SES in temporal terms. Fishermen and city workers attribute direct responsibility to the salmon industry for having poisoned the waters. This attribution also touches the government at different levels: historically, for not having developed efficient regulations for the salmon industry; technically, for weak supervision of the dumping process; and politically, for minimizing the relevance of both. The link between the excess of stranding and the excess of dumping is thus established. As a representative of a local organization contends: "It wasn't the red tide, but the poisoning of waters due to the dumping of rotting fish authorized by Sernapesca [Chilean fishing agency] what contaminated the whole Island" (interview, fieldwork 2017). Some fishermen even go so far as to deny the harmful character of the algal bloom: "Companies dumping chemicals [to absorb odors from dead fish] triggered this crisis. That's contamination, because the red tide we know doesn't kill shellfish" (interview, fieldwork 2017).

According to this account, when the dumping operation was performed from 10 to 26 March 2016, 1 month before the stranding, fishermen had denounced the possible consequences to authorities. The emergence of an extraordinary situation was already anticipated by fishermen. However, it only grew into actuality as the stranding took place on 25 April 2016. At this point, past and present became thus tightly coupled as the "dumping of dead salmon" turned into the cause of the "stranded shellfish." New meaningful developments arise from this particular moment: first, a controversy on the origins of the crisis and, second, a movement backward to place the crisis into a historical context of social-ecological problems and forward to promote different interests regarding the future of the SES on Chiloe Island. We revise the first point now and the second one subsequently.

As fishermen establish the meaningful link between the facts of stranding and dumping, an unresolvable controversy on the dynamics of the crisis arises. For all actors involved, it becomes relevant to determine the exact movement of dead salmon: first, from their cages to the ships; second, from the ships to the dumping points; and, third, through the ocean currents after the dumping. At this stage, scientists from different Chilean universities gathered on a special panel appointed by the central government (the Red Tide Commission) stressed that global warming, the acidification of waters, an extreme El Niño current, an uncommon upwelling event along the Chilean coast, and the eutrophication of interior waters were considered concomitant factors explaining the algal bloom. As emphasized by the Chilean Association of Marine Biologists (2016:2): "The only clear thing with this microalgal bloom is that it is not a local scale phenomenon, and much less of local origin" (emphasis in original). This statement is equivalent to that of fishermen 
arguing that red tides do not kill shellfish, as radical as that, but in the opposite direction. Both claims constitute the epistemic core of the controversy.

Because the connection between dumping and stranding was established in the controversy, scientists also had to take into account the explanatory connection between both events. According to the Red Tide Commission (Buschmann et al. 2016:31), wind patterns, the temperature of the water, and marine currents show that "it is highly probable that the prevailing circulation during March and early April 2016 transported the dumped material to the west and northwest, and not back to the Chiloe coast," thereby excluding the dumping as a significant cause of the algal bloom. This account was disputed by NGOs. Greenpeace (2016), on the basis of satellite images and field samples, argued that the circulation of waters from dumping points led the salmon to the southeast and not to the north, allowing residues to act as a fertilizer for the microalgae that triggered the disaster. Dead salmon moving in opposite directions symbolize the dispute over causal attributions and the poisoning of waters, thereby increasing the uncertainty of the socialecological crisis.

\section{Third controversy: the meaning of mobilizations}

As we explained previously, the events leading to the crisis unfolded quickly in the course of almost a month: on 19 March 2016, the Chilean Ministry of Health decreed a ban on fishing and shellfish extraction because of the red tide; on 25 April, the stranding of shellfish took place; and on 29 April, the government declared Chiloe a "catastrophe zone." The situation took a significant turn when on 2 May fishermen mobilized in numbers at urban centers of the island protesting against the government's rather lukewarm actions. As protests grew bigger, on 5 May, fishermen, gatherers, divers, and inland workers, i.e., commerce, tourism, services, and professional associations, blocked access points to the island with flaming barricades. The setting up of barricades is the third major event of the crisis.

Barricades build borders, and borders simultaneously divide and unite. A woman from a local organization summarizes this point accurately:

\begin{abstract}
The beautiful and the miserable joined - the beauty of the spontaneous reaction, because neither of us was prepared for what was to come. It was an evening of flowing information: 'Listen! Animals died here and there. Something is happening!' We all stopped working and went to the square to talk about it. We were there just saying: 'This and that is going on. It's insulting. We have to do something.' (Interview, fieldwork 2017)
\end{abstract}

Fishermen, free fair workers, professionals, and intellectuals joined the demonstration. Barricades were set up in strategic points of the island's main cities. Turns were taken to alternatively attend work and be out on the street: "It arose from anger; it was beautiful how everyone voluntarily joined. Chiloe paralyzed," recalls a woman from a local organization (interview, fieldwork 2017).

The barricade thus becomes a hub of multiple meaningful connections that reveals the deep historical roots of the socialecological crisis for Chiloe's inhabitants and their holistic and complex view on the causes of the problem. It constitutes the point at which controversial experiences reconstruct a memory of the SES that goes far beyond the stranding of shellfish and the dumping of salmon. Stranding and dumping do not become irrelevant, but the protest movement frames them within an expanded horizon of meanings covering several historical disappointments. They include, inter alia, the nonattended demands for decentralization of administrative decisions and more effective social services; a weak connectivity between the island and mainland and within the southern archipelago of Chiloe; the need for productive diversification; the uncertainty about the emerging mining industry; and conflicting relations with the salmon industry. As a representative of a fishing union explains, none of this was really new: "It comes from long ago, from the origins of Chile as a country: the Chilean State has always pushed regions into the background ... There has to be decentralization, so we have more regional powers" (interview, fieldwork 2017).

After the barricades expanded, the central government had to take action as local authorities lost legitimacy as intermediaries: "[They] saw how the crisis unfolded, how it escalated, and didn't do anything. Now neighbours are called upon to demand from the Chilean State to curb the crisis" (interview with representative of social assembly, fieldwork 2017). A "coordinating minister" was mandated to organize a round table in the regional capital city Puerto Montt, outside the island. At the negotiations, representatives of the social movement brought to the fore the all-encompassing concept of historical disappointments, whereas the government focused on the red tide problem and its immediate material consequences, i.e., unemployment, restricted means of livelihood, and blocked access points. Meanwhile, food and gasoline were running low on the island because of the barricades, and commerce came to a relative halt over more than 15 days.

The round table acted as a strong filter of the historical demands of Chiloe's inhabitants. It hid their long-lasting fragilities and translated the past, i.e., historical disappointments, into an instrumental discussion over cash bonuses and future plans mostly related to sea workers ("El acuerdo alcanzado entre el Gobierno y pescadores de seis localidades de Chiloé" 2016). In doing so, the round table worked as a communicative counterbarricade that contained overflows in meaning and drastically reduced the complexity of the social-ecological crisis to a number of technical questions: Who are the affected families entitled to receive the bonus? How can this be done to avoid double compensations to one family? When will the bill on fishing and shellfish extraction be passed? Who is in charge of drafting plans and setting up commissions? Because 15 different communities negotiated separately with the government, these questions were answered differently across the island. Fragmentation led social representatives to regret the results obtained: "Leaders are not capable of coming to an agreement with each other ... Groups negotiate individually [and do not] put the most relevant things for Chiloe's archipelago at the centre" (interview with representative of local organization, fieldwork 2017).

The final agreement included a bonus equivalent to US\$1,200 and action plans on fishing, environmental prospection, and economic reactivation. Still, dissatisfaction grew among fishermen, inland workers, and social organizations. As one fisherman declares: "We didn't get ourselves mobilized to obtain 
Fig. 3. Main communication topics before the crisis: March 2013 to February 2016.

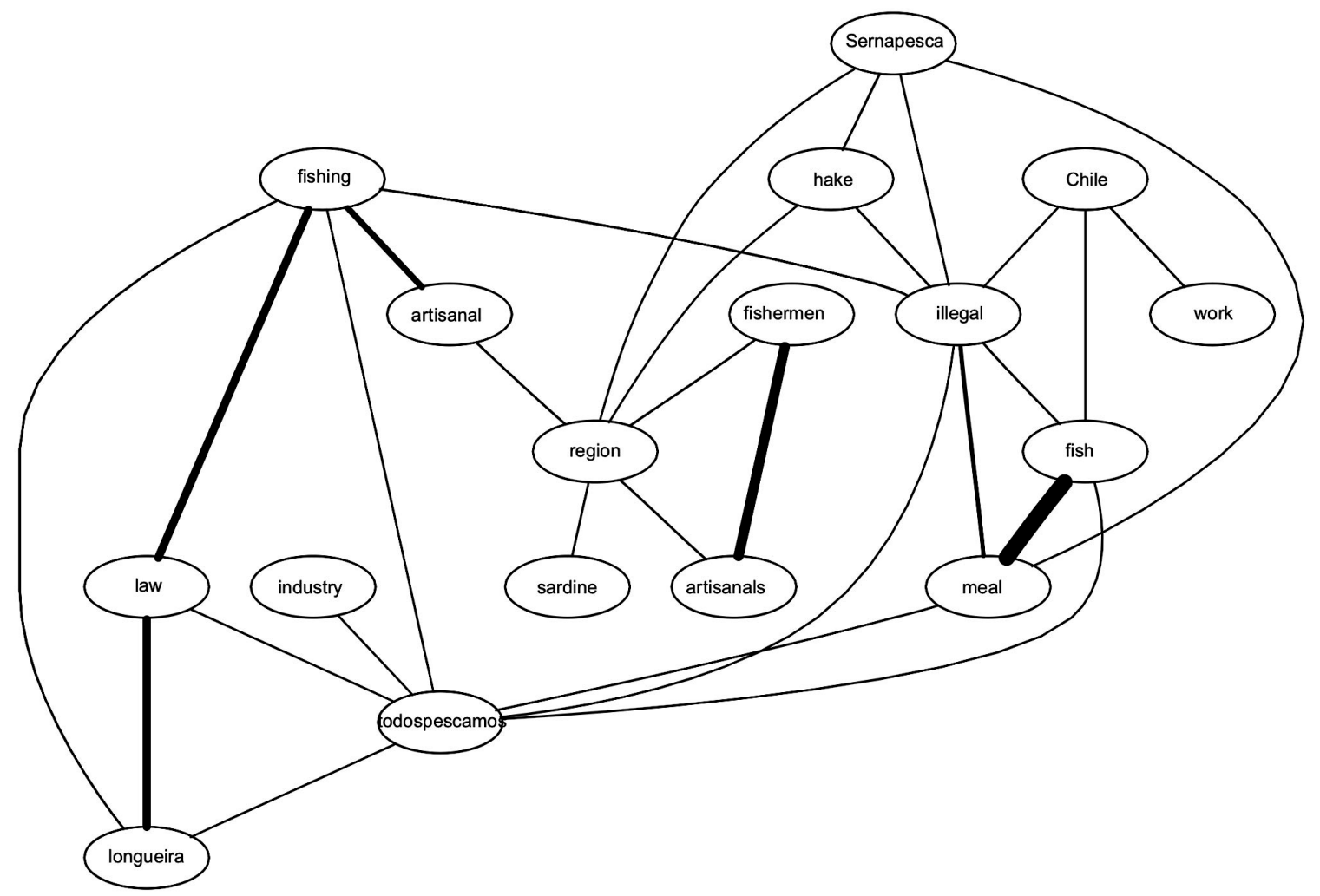

a bonus ... What did we want? We wanted an integral plan for the Island" (interview, fieldwork 2017). Others express a more disenchanted view on the persistence of the stresses leading to the crisis: "The problem is not solved ... we still have to be vigilant" (interview with woman from local organization, fieldwork 2017). The government had managed the crisis through short-run measures and deactivated its most conflictive manifestation by displacing unsolved historical problems into the future. The movement was successful in forcing the government to negotiations, but the negotiations reduced the problem to shorttermed instrumental goals.

\section{Controversial communications in social media}

We analyze prevalent topics of communication in social media before, during, and after the critical events on Chiloe. We aim to show the general communicative framework in which the controversies took place and how it changed over time. Figures 3,4 , and 5, illustrate the main topics of communication in three periods. The intensity of lines represents the frequency of association.

The period before the critical events (Fig. 3) is dominated by national political discussions on the regulation of fishing activities affecting particularly artisanal fishermen and favoring the fishing industry. Relevant topics of communication are rather fragmented into "law on fishing," "artisanal fishermen," "fish meal," and "illegal fishing." However, these topics carry significant connections for regional actors insofar as they are related to the conflicting interaction between local communities and the Chilean state. They also reveal the systemic entanglement of everyday life on Chiloe Island with the fishing industry and sea-related commercial activities. As the crisis broke up on March 2016, this entanglement facilitated the rather sudden shift of the red tide event into a major social-ecological crisis.

In the period during the critical events (Fig. 4), communication becomes governed by the topics "red tide" and "dumping of salmon." Interestingly, the "government" also emerges as a secondary hub because of its responsibility regarding the crisis. All of these concepts correlate with the previously described controversies. To that extent, Twitter data reflect a shift in communication topics from a more decentralized web to a concentration into two dominant topics.

In the period after the crisis (Fig. 5), "red tide" remains the most relevant topic of communication. "Artisanal fishermen" and "legislation" are secondary topics. This reveals that discussions at the round table organized by the government in May 2016 remained a significant reference point in the communication of the island's inhabitants throughout 2016. "Legislation" and "governmental bidding" for financing social interventions were two mechanisms designed to respond to the problems raised by Chiloe's inhabitants during the dialogue. Word associations cannot tell us whether the promises were actually accomplished, but they do inform us about the high expectations put on those mechanisms as the means to deal with the social-ecological crisis and its aftermath. 
Fig. 4. Main communication topics during the crisis: March to May 2016.

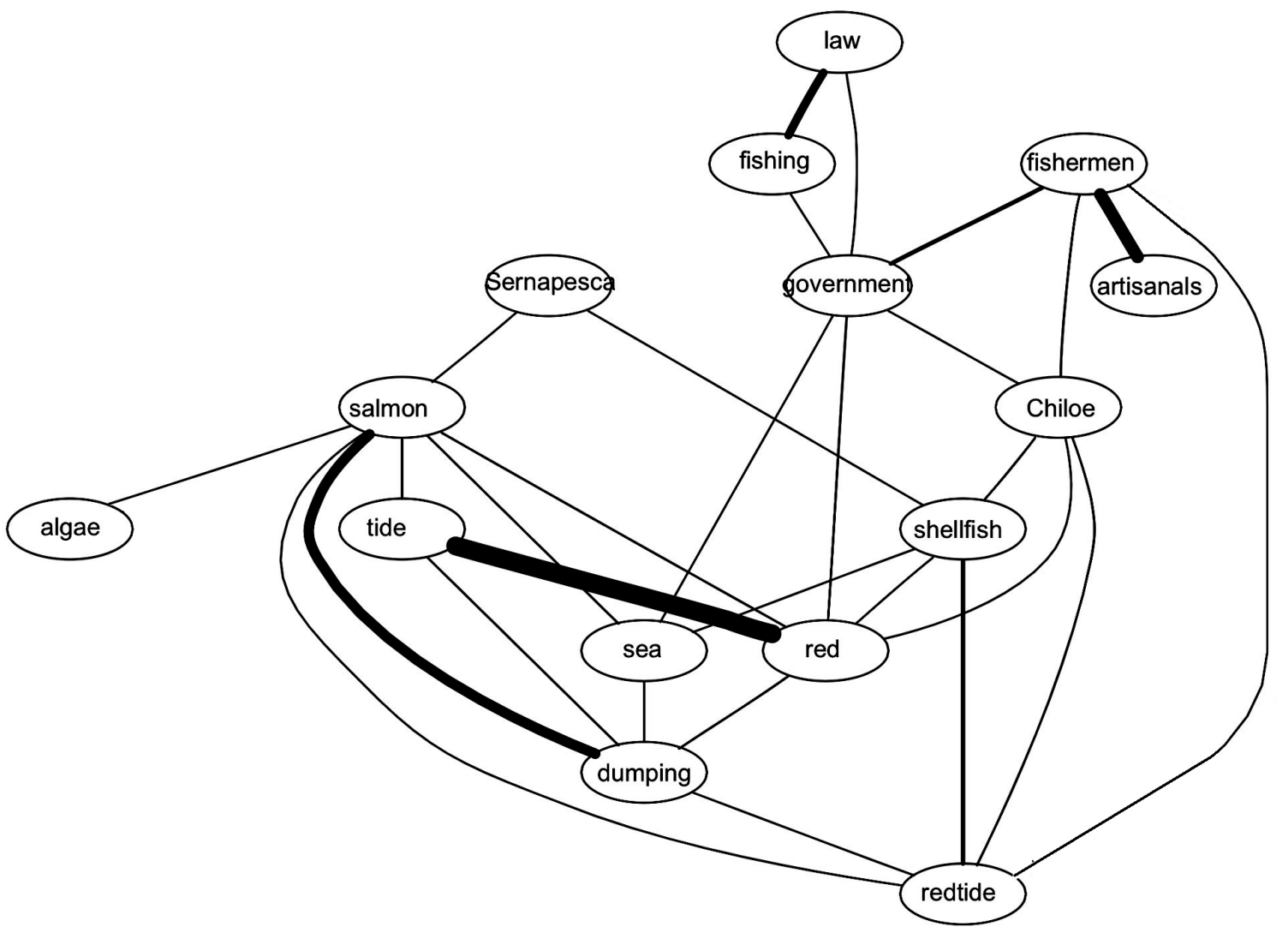

\section{DISCUSSION}

Visible and hidden fragilities in Chiloe's social-ecological system: locks and shifts

Building from previous theoretical and empirical analyses, we can characterize Chiloe Island's SES as an unstable regime with inherent fragilities. From a historical perspective, Chiloe Island has been a laboratory of accelerated modernization processes. In less than three decades, it has moved from being a rural and isolated region to a global platform for transnational aquaculture companies, thereby unleashing multiple dynamics at different scales: from a subsistence economy to the marketization of land and labor, from embedded social practices of production to disembedded global exploitation techniques for which governance mechanisms must be constantly reinvented, and from rather stable ecological interactions to an overloaded SES prone to eutrophication and sudden regime shifts (Barton and Fløysand 2010, Barton and Román 2016, Tecklin 2016).

As a general statement, we can observe that Chiloe's SES has progressively developed inherent fragilities, visible and hidden, that seriously affect its resilience, i.e., its capacities to support human well-being by adapting to the changing conditions of an increasingly complex ecological landscape. From ecological silence in the 1980s to the economic imperatives of the 1990s and the global standards of the 2000s onward, Chiloe's SES has managed near to criticality (Bak 1996, Yorke et al. 2002, Folke et al. 2016). In other words, the SES has moved between cycles of expansion of exploitative activities of the salmon industry (efficiency locks) and periods of high instability, usually after significant crises of this industry, i.e., the SRS crisis in 1989, the ISA crisis in 2007, and the red tide crisis in 2016. Such collapses in Chiloe's socio-natural conditions, and the need for reinventing the institutional framework from time to time, have made rather difficult the incremental task of building system resilience, i.e., learning, adaptation, and transformation.

These fragilities of Chiloe's SES are recognized in the literature. We can call them visible fragilities. What the analysis of controversies shows is that there are other, rather hidden fragilities at lower scales that also affect the general resilience of the SES. They are condensed into the experiential concept of "historical disappointments" built by Chiloe's inhabitants during the mobilizations. The concept articulates a range of unsatisfactory experiences of inhabitants with major social structures that identify lock-in mechanisms (Scheffer 2009) at different scales: centralization in decision making, productive dependence in industrial organization, problems of connectivity within the archipelago, restricted access and quality of social services, and inefficient regulation of the salmon industry. It seems that in spite of previous opportunities of change opened up by past crises, inertia prevails in Chiloe's SES: The exploitative economic activities grow and become more robust but without major changes in the social-ecological network that supports both social and natural forms of life. 
Fig. 5. Main communication topics after the crisis: June 2016 to January 2017.

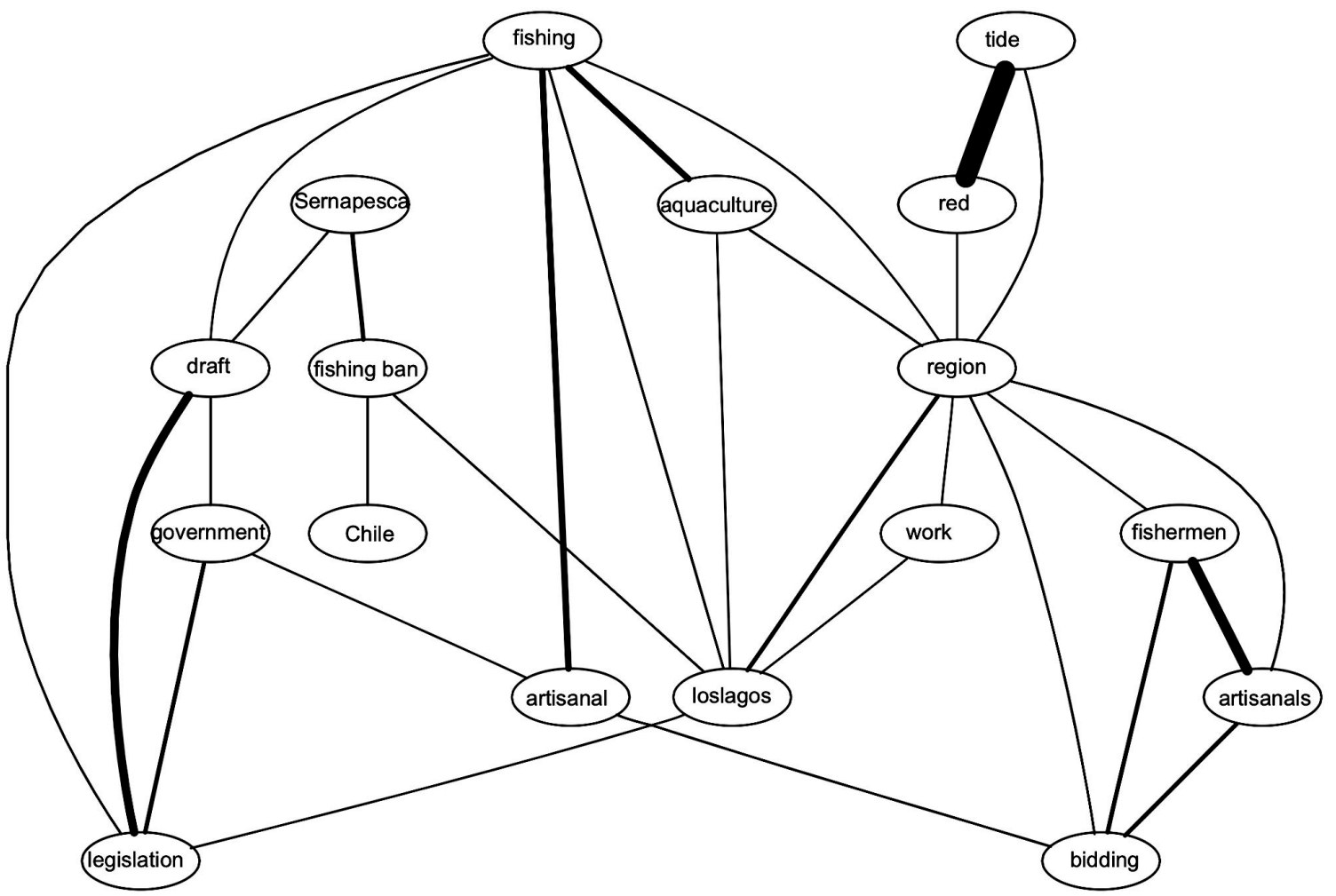

Therefore, a gap remains open between the commercially oriented mode of production of a global industry with visible fragilities, i.e., homogeneity of procedures and species, proximity and interconnectivity of concessions, and exploitative and nonexplorative approach, and the rather hidden fragilities of the SES, i.e., centralization, dependence, inefficient regulations, and connectivity problems. This has made the social life of Chiloe communities extremely dependent on two basins of attraction: the decision making of both the global aquaculture industry and the central state. In other words, instead of learning, adapting, and smoothly transforming itself, Chiloe's SES learns to move at the edge, jumping from crisis to crisis. It waits for failure as a form of self-management. It is for this reason that Chiloe's inhabitants consider the 2016 red tide crisis another layer in a long history of disappointments.

The analysis of Twitter data and controversies supports this interpretation. Twitter data also show interesting communication shifts: From a more decentralized topology before the crisis (Fig. 3), communication jumps to a concentration on the red tide and the dumping of salmon (Fig. 4). In addition, topics related to the central state, i.e., law, legislation, and Sernapesca, are a background layer of communication in the three periods. Remarkably, the topic "red tide," which appears in the period during the crisis (Fig. 4), remains in the next period (Fig. 5) as a central topic, revealing a permanent shift in the dynamics of communication.

\section{Epistemic and political divisions in Chiloe's social-ecological system}

Considering the development of controversies, right after the stranding of shellfish, the government established the Red Tide Commission. While the commission considered a range of possible causes of Chiloe's red tide, the government selected the less specific ones for constructing the public discourse: global warming and the El Niño current. Political power thus quickly aligned scientific knowledge to its goals by excluding causes of social-ecological origins, such as the concentration of nitrogen in the central exterior coast of Chiloe (Abtao; Buschmann et al. 2016:46), which prior scientific research had correlated with intensive salmon farming in this region (Buschmann et al. 2006). This could have been a bridge between contrasting positions. However, politics construed its own science. The immediate effect of this alignment was the epistemic division of the SES. As the political-scientific discourse thought of nature as ontologically natural, it excluded from the discussion a consideration of the complex dynamics of the SES, as fishermen and NGOs insistently did from the outset of the controversy. This epistemic antithesis created a political division of the SES in which government/ scientists and fishermen/NGOs became opponents.

This scenario of epistemic and political division of the SES allowed the salmon industry to take a back seat in the controversy, for its position was represented by the political-scientific discourse. In one of the few public interventions, the president of SalmonChile AG at that time declared: "It is a natural phenomenon; SalmonChile has nothing to do with it ... The 
industry was unfairly blamed for the red tide outbreak in the zone; [this attribution] was discredited by independent scientists appointed by the government" (Balcazar 2016, "Felipe Sandoval se refiere a su salida de SalmónChile" 2017). According to two short interviews allowed by representatives of the salmon industry, the red tide was unpredictable and unmanageable and, therefore, confronted the industry with financial and reputational problems. Still, representatives of the industry were themselves divided on whether to follow a business as usual model after the crisis (SalmonChile AG) or a more integral transformation of the governance regime of the industry, including production quotes (Marine Harvest; interview with representative of the salmon industry, fieldwork 2017). Theoretically put, they were divided between continuing with the exploitative behavioral lock and the exploration of new strategies (Scheffer 2009).

Thinking of nature as ontologically natural, i.e., dividing the SES, resolved several problems in the political ecology of the conflict. It allowed the salmon industry to remain behind the curtains of the controversy because the problem was "natural" and not "social." Because there was nothing humans could do against the forces of nature, as in mythical thinking, the government could scale down the conflict and encapsulate the protests as a matter of unemployment. Insomuch as the problem was circumscribed to short-term economic issues, the government was able to postpone the discussion on the "historical disappointments" with fishing communities and also avoided having to negotiate with the salmon industry a path out of the prevailing governance regime of Chiloe's SES. In so doing, the visible fragilities were ignored and the hidden fragilities politically displaced to the future. This explains why representatives of social movements were so disappointed with the results of the negotiations. The opportunity to build new forms of resilience and deactivate behavioral locks was lost.

However, the social resources that came to light with the controversies and protests reveal pathways for improving the governance regime of Chiloe Island's SES. Chile shows some positive experiences in adaptive governance of marine resources. Essential for having success in this effort is articulating links between the local level and processes of decision making at the national level (Gelcich et al. 2010, Basurto et al. 2013). Controversies have made clear that Chiloe's inhabitants possess comprehensive knowledge on the properties of their SES. First of all, they do not divide the SES into a natural and a social dimension, as the political-scientific discourse did. Second, past experiences have taught them how to deal with red tides and to differentiate between a regular and an extraordinary red tide event. Third, they are also aware of the structural-historical problems of the island, i.e., the "historical disappointments" in the semantics of mobilizations, or the hidden fragilities in SEStheory language. Fourth, because of the historical experience with those problems, Chiloe's inhabitants are able to visualize and make compatible long-term and short-term solutions in a more holistic social-ecological way.

As the first and second controversies demonstrate, Chiloe's inhabitants, supported by technical knowledge of the transnational NGO Greenpeace, disputed the truth of both the causes of the red tide and the movement of dead salmon after the dumping. Their knowledge was robust enough to put the politicalscientific discourse under scrutiny, and their practical resources were strong enough to institutionally scale that dispute. In a recent decision, the Chilean Supreme Court ruled in their favor (Supreme Court of Chile 2018). It declared illegal the dumping of dead salmon on two grounds: first, the international Convention on the Prevention of Marine Pollution by Dumping of Wastes and Other Matter signed by Chile in 1977, and second, article 19, number 8 of the Chilean Constitution, which protects the right to live in an environment free of contamination.

\section{Chiloe's networking capacities}

Controversies and protests have also made clear that Chiloe's inhabitants are capable of activating and constructing multiple networks for the mobilization of resources. In the case of the 2016 Chiloe red tide crisis, these networks developed at different scales. The most obvious one is the network that links sea and inland workers through commercial and service activities. As the massive stranding of shellfish took place, the practical goal of this network suddenly shifted from economic exchange to collective action and became the foundation of the movement until the end of mobilizations.

Although the topology of this network is local in its origins, it develops another branch linking local to global actors. The transnational organization Greenpeace plays a key role in supporting the local network with scientific knowledge and wider media attention. The thus extended social movement could dispute the truth regarding the causes of the red tide not only by drawing on the valuable resources of local, practical knowledge, but also by mobilizing scientific arguments and evidence. The movement was able to integrate both regimes of truth, the scientific and the practical knowledge, reuniting the divided SES of the political-scientific discourse.

In addition, transnational media networks such as the BBC, the Guardian, and the New York Times were fundamental to shifting the scale on which the Chiloe red tide crisis was being seeing and discussed. It developed from a local story to a critical event in the global public sphere and biosphere. This allowed the social movement to gain not only visibility, but also transnational support and legitimacy, thereby counterbalancing the power of the alignment between the political-scientific discourse and the salmon industry.

Another network at the national scale developed after the crisis between local actors, legal devices, and the national system of law. In January 2017, four Chiloe sea worker unions filed an application for protection to the Puerto Montt Appellation Court against the Chilean maritime authority, Directemar, the National Service for Fishing and Aquaculture (Sernapesca), the Superintendence of the Environment, and the Regional Ministry of Health for allowing the dumping of 9000 dead salmon into the sea. As cited previously, the Supreme Court of Chile upheld the application in May 2018, declaring that all named institutions "shall take, within two months, preventive, corrective, and procedural coordination measures ... in order to avoid hazards for public health and damages to the environment" (Supreme Court of Chile 2018:15). The outcome of this network establishes mandatory rules that may contribute to transform the border conditions of Chiloe's SES. 
For a new adaptive governance of Chiloe's SES, it is necessary to reactivate and interconnect these different network levels (Folke et al. 2005, Barton and Fløysand 2010, Österblom et al. 2013). As seen, there are incentives for all levels to engage in this effort. The court's decision is not only a triumph for the position defended by Chiloe's inhabitants in the controversy. It also implies a binding obligation for the other involved actors, i.e., maritime authorities, the salmon industry, government, and even scientists, to revise their behavioral locks and reinvent the governance strategies of Chiloe's SES. This time, however, the search for agreements must not be conducted as in classical negotiations restricted to instrumental goals, e.g., the amount of bonuses. Rather than a zero-sum game, a positive-sum game is required. Deliberation systems (Willke 1995), for instance, promote discussion among equally legitimate stakeholders searching for coordination between diverging goals. They are not aimed at building consensus, but at establishing reliable forms of cooperation oriented to collaborative problem solving and the organization of policy networks. Hybrid forums (Callon et al. 2009) are another possibility that has been particularly designed to manage socio-technical controversies. They are discussion groups composed of heterogeneous agents involved in a controversial situation, e.g., politicians, experts, social actors, entrepreneurs, and technicians, who open themselves to experiment and learn in the search for a common world or identity.

Implementing governance strategies like these is certainly difficult, but their outcomes can be highly relevant for Chiloe's SES: The visible and hidden fragilities can be brought to the fore; the lock-in mechanisms can be observed and deactivated, thus reducing the probability of sudden regime shifts; and the connection of multiple networks can be articulated to increase resilience in a complex fashion. The 2016 red tide crisis in southern Chile shows how crucial this is in Chiloe's SES.

\section{CONCLUSIONS}

Building from the discussions on resilience and governance in SESs and from the analysis of social controversies in a major red tide crisis on Chiloe Island, Chile, in 2016, we have argued that Chiloe's SES is an unstable regime prone to sudden shifts. At the basis of this instability, we can identify different lock-in mechanisms expressed in visible fragilities, i.e., marketization, exploitation, and environmental overloading, and hidden fragilities, i.e., centralization, dependence, and inefficient regulations, that bring about loss of resilience.

From the examination of the social controversies produced in the red tide crisis, we can draw several lessons. First, SESs can learn to move at the edge of sudden transitions, using crises as a form of self-management. This is more likely when visible fragilities are ignored and the resolution of hidden fragilities is postponed to the future.

Second, controversial communication in critical situations can manipulate the epistemic construction of the SES dividing it into separated parts (natural and social) and presenting nature as ontologically natural. In doing this, actors can politically align to avoid their responsibility for having contributed to socialecological crises, as did the alignment between the politicalscientific discourse and the salmon industry.
Third, the experience of the crisis, i.e., sudden shifts at different levels, and disputes over truth in the controversies mobilize epistemic and political resources in local communities, i.e., holistic practical knowledge and networking capacities, that build a platform to improve the forms of governance of the SES.

Fourth, nonauthoritative forms of governance are required to fluidly connect different network levels that, in a logic of cooperation, i.e., positive-sum rather than zero-sum game, contribute to increase resilience in Chiloe's SES. Examples of these mechanisms are adaptive governance, deliberation systems, and hybrid forums.

A final lesson we can highlight is that the analysis of controversies in social-ecological crises plays a dual role. On the one hand, they offer a distinctive methodological approach to understand the dynamics of social-ecological crises as we have shown. However, on the other, controversies are also internal mechanisms of SESs that do not need to be avoided but managed to cope with problems of resilience and take benefit from windows of opportunity opened by critical situations to improve the governance of SESs.

Responses to this article can be read online at: http://www.ecologyandsociety.org/issues/responses. php/10300

\section{Acknowledgments:}

The authors thank the Research Centre Models of Crises (NS 130017) for financially supporting this research. We also thank Ricardo Truffello for Figure 1 and the reviewers of Ecology and Society for insightful comments.

\section{LITERATURE CITED}

Ahlborg, H., and A. J. Nightingale. 2012. Mismatch between scales of knowledge in Nepalese forestry: epistemology, power, and policy implications. Ecology and Society 17(4):16. http://dx. doi.org/10.5751/ES-05171-170416

Anderies, J. M., C. Folke, B. Walker, and E. Ostrom. 2013. Aligning key concepts for global change policy: robustness, resilience, and sustainability. Ecology and Society 18(2):8. http:// dx.doi.org/10.5751/ES-05178-180208

Anderies, J. M., P. Ryan, and B. H. Walker. 2006. Loss of resilience, crisis, and institutional change: lessons from an intensive agricultural system in southeastern Australia. Ecosystems 9:865-878. http://dx.doi.org/10.1007/s10021-006-0017-1

Anderson, D. 1989. Toxic algal blooms and red tides: a global perspective. Pages 11-16 in T. Okaichi, D. Anderson, and T. Nemoto, editors. Red tides: biology, environmental science, and toxicology. Elsevier, New York, New York, USA.

Anderson, D. M. 1994. Red tides. Scientific American 271 (2):62-68. http://dx.doi.org/10.1038/scientificamerican0894-62

Anderson, D. M. 2009. Approaches to monitoring, control and management of harmful algal blooms (HABs). Ocean \& Coastal Management 52(7):342-347. http://dx.doi.org/10.1016/j. ocecoaman.2009.04.006 
Bak, P. 1996. How nature works. Springer, New York, New York, USA. http://dx.doi.org/10.1007/978-1-4757-5426-1

Balcazar, S. 2016. Felipe Sandoval, ex Subsecretario de Pesca y su rol como president de SalmónChile: "No le veo ningún problema." El Desconcierto, 18 May. [online] URL: http://www. eldesconcierto.c1/2016/05/18/felipe-sandoval-ex-subsecretario-depesca-y-su-rol-como-presidente-de-salmon-chile-no-le-veo-ningunproblemal

Barton, J. R., and A. Fløysand. 2010. The political ecology of Chilean salmon aquaculture, 1982-2010: a trajectory from economic development to global sustainability. Global Environmental Change 20:739-752. http://dx.doi.org/10.1016/j. gloenvcha.2010.04.001

Barton, J., and A. Román. 2016. Sustainable development? Salmon aquaculture and late modernity in the Archipelago of Chiloé, Chile. Island Studies Journal 11(2):651-672.

Basurto, X., S. Gelcich, and E. Ostrom. 2013. The socialecological system framework as a knowledge classificatory system for benthic small-scale fisheries. Global Environmental Change 23:1366-1380. http://dx.doi.org/10.1016/j.gloenvcha.2013.08.001

Bryant, R. L. 1998. Power, knowledge, and political ecology in the third world: a review. Progress in Physical Geography 22 (1):79-94. http://dx.doi.org/10.1177/030913339802200104

Buschmann, A., L. Farías, F. Tapia, D. Varela, and M. Vásquez. 2016. Informe final Comisión Marea Roja. Academia Chilena de Ciencias, Santiago, Chile. [online] URL: http://www. academiadeciencias.cl/wp-content/uploads/2017/04/

InfoFinal ComisionMareaRoja 21Nov2016.pdf

Buschmann, A. H., V. A. Riquelme, M. C. Hernández-González, D. Varela, J. E. Jiménez, L. A. Henríquez, P. A. Vergara, R. Guíñez, and L. Filún. 2006. A review of the impacts of salmonid farming on marine coastal ecosystems in the southeast Pacific. ICES Journal of Marine Science 63(7):1338-1345. http://dx.doi. org/10.1016/i.icesims.2006.04.021

Cabello, F. C., and H. P. Godfrey. 2016. Florecimiento de algas nocivas (FANs), ecosistemas marinos y la salud humana en la Patagonia chilena. Revista Chilena de Infectología 33(5):559-560. http://dx.doi.org/10.4067/S0716-10182016000500011

Callon, M. 1984. Some elements of a sociology of translation: domestication of the scallops and the fishermen of St Brieuc Bay. Sociological Review 32(S1):196-233. http://dx.doi.org/10.1111/ j.1467-954X.1984.tb00113.X

Callon, M., P. Lascoumes, and Y. Barthe. 2009. Acting in an uncertain world. MIT Press, Cambridge, Massachusetts, USA.

Carpenter, S., B. Walker, J. M. Anderies, and N. Abel. 2001. From metaphor to measurement: resilience of what to what? Ecosystems 4:765-781. http://dx.doi.org/10.1007/s10021-001-0045-9

Chilean Association of Marine Biologists. 2016. Public declaration. Chilean Association of Marine Biologists A.G., Santiago, Chile. [online] URL: http://slideflix.net/doc/62689/ como-biólogos-marinos-ag-nos-preocupa-el-nivel-de

El acuerdo alcanzado entre el Gobierno y pescadores de seis localidades de Chiloé. 2016. Cooperativa.cl. 15 May. [online]
URL: https://www.cooperativa.cl/noticias/pais/region-de-los-lagos/ el-acuerdo-alcanzado-entre-el-gobierno-y-pescadores-de-seislocalidades/2016-05-14/204730.html

Felipe Sandoval se refiere a su salida de SalmonChile. 2017. Aqua. 1 December. [online] URL: http://www.aqua.cl/2017/12/01/ felipe-sandoval-responde-por-su-salida-de-salmonchile/\#

Folke, C. 2006. Resilience: the emergence of a perspective for social-ecological systems analyses. Global Environmental Change 16:253-267. http://dx.doi.org/10.1016/j.gloenvcha.2006.04.002

Folke, C. 2016. Resilience (republished). Ecology and Society 21 (4):44. http://dx.doi.org/10.5751/ES-09088-210444

Folke, C., R. Biggs, A. V. Norström, B. Reyers, and J. Rockström. 2016. Social-ecological resilience and biosphere-based sustainability science. Ecology and Society 21(3):41. http://dx.doi.org/10.5751/ ES-08748-210341

Folke, C., S. R. Carpenter, B. Walker, M. Scheffer, T. Chapin, and J. Rockström. 2010. Resilience thinking: integrating resilience, adaptability and transformability. Ecology and Society 15(4):20. http://dx.doi.org/10.5751/ES-03610-150420

Folke, C., S. Carpenter, B. Walker, M. Scheffer, T. Elmqvist, L. Gunderson, and C. S. Holling. 2004. Regime shifts, resilience, and biodiversity in ecosystem management. Annual Review of Ecology, Evolution, and Systematics 35:557-581. http://dx.doi. org/10.1146/annurev.ecolsys.35.021103.105711

Folke, C., T. Hahn, P. Olsson, and J. Norberg. 2005. Adaptive governance of social-ecological systems. Annual Review of Environment and Resources 30:441-473. http://dx.doi.org/10.1146/ annurev.energy.30.050504.144511

Gelcich, S., T. P. Hughes, P. Olsson, C. Folke, O. Defeo, M. Fernández, S. Foale, L. H. Gunderson, C. Rodriguez-Sickert, M. Scheffer, R. S. Steneck, and J. C. Castilla. 2010. Navigating transformations in governance of Chilean marine coastal resources. Proceedings of the National Academy of Sciences of the United States of America 107:16794-16799. http://dx.doi. org/10.1073/pnas.1012021107

Glibert, P. M., J. I. Allen, Y. Artioli, A. Beusen, L. Bouwman, J. Harle, R. Holmes, and J. Holt. 2014. Vulnerability of coastal ecosystems to changes in harmful algal bloom distribution in response to climate change: projections based on model analysis. Global Change Biology 20:3845-3858. http://dx.doi.org/10.1111/ gcb. 12662

Glibert, P. M., A. H. W. Beusen, J. A. Harrison, H. H. Dürr, A. F. Bouwman, and G. G. Laruelle. 2018. Changing land-, sea-, and airscapes: sources of nutrient pollution affecting habitat suitability for harmful algae. Pages 53-76 in P. Glibert, E. Berdalet, M. Burford, G. Pitcher, and M. Zhou, editors. Global ecology and oceanography of harmful algal blooms. Ecological Studies (Analysis and Synthesis), Volume 232. Springer, Cham, Switzerland. http://dx.doi.org/10.1007/978-3-319-70069-4_4

González, S. 2016. Red tide and labor unrest reduce Chilean salmon production. Global Agricultural Information Network (GAIN) Report No. CI1611. GAIN, USDA Foreign Agricultural Service, Washington, D.C., USA. 
Greenpeace. 2016. Reporte Crisis Social Ambiental en Chiloé: Resumen Ejecutivo. Greenpeace, Amsterdam, The Netherlands.

Guzmán, L., H. Pacheco, G. Pizarro, and C. Alarcón. 2002. Alexandrium catenella y veneno paralizante de los mariscos en Chile. Pages 237-256 in E. Sar, M. Ferrario, and B. Reguera, editors. Floraciones algales nocivas en el Cono Sur Americano. Instituto Español de Oceanografía, Madrid, Spain.

Hahn, T., P. Olsson, C. Folke, and K. Johansson. 2006. Trustbuilding, knowledge generation and organizational innovations: the role of a bridging organization for adaptive comanagement of a wetland landscape around Kristianstad, Sweden. Human Ecology 34:573-592. http://dx.doi.org/10.1007/s10745-006-9035$\underline{z}$

Heisler, J., P. M. Glibert, J. M. Burkholder, D. M. Anderson, W. Cochlan, W. C. Dennison, Q. Dortch, C. J. Gobler, C. A. Heil, E. Humphries, A. Lewitus, R. Magnien, H. G. Marshall, K. Sellner, D. A. Stockwell, D. K. Stoecker, and M. Suddleson. 2008. Eutrophication and harmful algal blooms: a scientific consensus. Harmful Algae 8:3-13. http://dx.doi.org/10.1016/j.hal.2008.08.006

Holling, C. S. 1973. Resilience and stability of ecological systems. Annual Review of Ecology and Systematics 4:1-23. http://dx.doi. org/10.1146/annurev.es.04.110173.000245

Holling, C. S., and L. Gunderson. 2002. Resilience and adaptive cycles. Pages 25-62 in L. Gunderson and C. S. Holling, editors. Panarchy. Island, Washington, D.C., USA.

Holling, C. S., L. Gunderson, and D. Ludwig. 2002. In quest of a theory of adaptive change. Pages 3-22 in L. Gunderson and C. S. Holling, editors. Panarchy. Island, Washington, D.C., USA.

Holling, C. S., and G. K. Meffe. 1996. Command and control and the pathology of natural resource management. Conservation Biology 10(2):328-337. http://dx.doi.org/10.1046/

j.1523-1739.1996.10020328.x

Homer-Dixon, T., B. Walker, R. Biggs, A.-S. Crépin, C. Folke, E. F. Lambin, G. D. Peterson, J. Rockström, M. Scheffer, W. Steffen, and M. Troell. 2015. Synchronous failure: the emerging causal architecture of global crisis. Ecology and Society 20(3):6. http:// dx.doi.org/10.5751/ES-07681-200306

Iizuka, M., and J. P. Zanlungo. 2016. Environmental collapse and institutional restructuring: the sanitary crisis in the Chilean salmon industry. Pages 109-135 in A. Hosono, M. Iizuka, and J. Katz, editors. Chile's salmon industry: policy challenges in managing public goods. Springer, Tokyo, Japan. http://dx.doi. org/10.1007/978-4-431-55766-1 5

Kirkpatrick, B., K. Kohler, M. M. Byrne, and J. Studts. 2014. Florida red tide knowledge and risk perception: is there a need for tailored messaging? Harmful Algae 32:27-32. http://dx.doi. org/10.1016/j.hal.2013.09.008

Kruke, B I., and O. E. Olsen. 2012. Knowledge creation and reliable decision-making in complex emergencies. Disasters 36 (2):212-232. http://dx.doi.org/10.1111/j.1467-7717.2011.01255.x

Kuhar, S. E., K. Nierenberg, B. Kirkpatrick, and G. A. Tobin. 2009. Public perceptions of Florida red tide risks. Risk Analysis 29(7):963-969. http://dx.doi.org/10.1111/j.1539-6924.2009.01228. $\underline{x}$
Latour, B. 1987. Science in action. Harvard University Press, Cambridge, Massachusetts, USA.

Latour, B. 2005. Reassembling the social. Oxford University Press, Oxford, UK.

León-Muñoz, J., M. A. Urbina, R. Garreaud, and J. L. Iriarte. 2018. Hydroclimatic conditions trigger record harmful algal bloom in western Patagonia (summer 2016). Scientific Reports 8:1330. http://dx.doi.org/10.1038/s41598-018-19461-4

Masiva varazón de machas genera preocupación en pescadores de Chiloé. 2016. 24 Horas. cl TVN. 28 April. [online] URL: http:// www.24horas.cl/nacional/masiva-varazon-de-machas-generapreocupacion-en-pescadores-de-chiloe-2000473\#

Ministry of Health. 2016. Resolución exenta 484. Government of Chile, Santiago, Chile.

Ministry of the Interior. 2016. Decreto 499. Government of Chile, Santiago, Chile.

Nierenberg, K., M. M. Byrne, L. E. Fleming, W. Stephan, A. Reich, L. C. Backer, E. Tanga, D. R. Dalpra, and B. Kirkpatrick. 2010. Florida red tide perception: residents versus tourists. Harmful Algae 9:600-606. http://dx.doi.org/10.1016/j.hal.2010.04.010

Okaichi, T. 2010. Red tides. Kluwer Academic, Dordrecht, The Netherlands.

Olsson, P., C. Folke, and T. Hahn. 2004. Social-ecological transformation for ecosystem management: the development of adaptive co-management of a wetland landscape in southern Sweden. Ecology and Society 9(4):2. http://dx.doi.org/10.5751/ ES-00683-090402

Olsson, L., A. Jerneck, H. Thoren, J. Persson, and D. O’Byrne. 2015. Why resilience is unappealing to social science: theoretical and empirical investigations of the scientific use of resilience. Science Advances 1(4):e1400217. http://dx.doi.org/10.1126/ sciadv. 1400217

Österblom, H., and C. Folke. 2013. Emergence of global adaptive governance for stewardship of regional marine resources. Ecology and Society 18(2):4. http://dx.doi.org/10.5751/ES-05373-180204

Scheffer, M. 2009. Critical transitions in nature and society. Princeton University Press, Princeton, New Jersey, USA.

Scheffer, M., and S. R. Carpenter. 2003. Catastrophic regime shifts in ecosystems: linking theory to observation. Trends in Ecology \& Evolution 18(12):648-665. http://dx.doi.org/10.1016/j. tree.2003.09.002

Scheffer, M., S. R. Carpenter, J. A. Foley, C. Folke, and B. Walker. 2001. Catastrophic shifts in ecosystems. Nature 413:591-596. http://dx.doi.org/10.1038/35098000

Scheffer, M., and F. R. Westley. 2007. The evolutionary basis of rigidity: locks in cells, minds, and society. Ecology \& Society 12 (2):36. http://dx.doi.org/10.5751/ES-02275-120236

Servicio Nacional de Pesca y Acuicultura (Sernapesca). $2016 a$. Informe de fiscalización de Resolución 12.600/05/114/vrs. Sernapesca, Valparaíso, Chile.

Servicio Nacional de Pesca y Acuicultura (Sernapesca). $2016 b$. Informe de la Resolución D.G.T.M y M.M. ORD. $N^{\circ}$ 
12.600/05/114/VRS de la Autoridad Maritima relativa al vertimiento de desechos de salmones. Sernapesca, Valparaíso, Chile.

Supreme Court of Chile. 2018. Docket $N^{o}$ 34.594-2017. 22 May. Supreme Court of Chile, Santiago, Chile.

Tecklin, D. 2016. Sensing the limits of fixed marine property rights in changing coastal ecosystems: salmon aquaculture concessions, crises, and governance challenges in southern Chile. Journal of International Wildlife Law \& Policy 19(4):284-300. http://dx.doi. org/10.1080/13880292.2016.1248647

Walker, B. H., N. Abel, J. M. Anderies, and P. Ryan. 2009. Resilience, adaptability, and transformability in the Goulburn Broken Catchment, Australia. Ecology and Society 14(1):12. http://dx.doi.org/10.5751/ES-02824-140112

Walters, C. 1997. Challenges in adaptive management of riparian and coastal ecosystems. Conservation Ecology 1(2):1. http://dx. doi.org/10.5751/ES-00026-010201

Wells, M. L., V. L. Trainer, T. J. Smayda, B. S. O. Karlson, C. G. Trick, R. M. Kudela, A. Ishikawa, S. Bernard, A. Wulff, D. M. Anderson, and W. P. Cochlan. 2015. Harmful algal blooms and climate change: learning from the past and present to forecast the future. Harmful Algae 49:68-93. http://dx.doi.org/10.1016/j. $\underline{\text { hal.2015.07.009 }}$

Westley, F. R., O. Tjornbo, L. Schultz, P. Olsson, C. Folke, B. Crona, and Ö. Bodin. 2013. A theory of transformative agency in linked social-ecological systems. Ecology and Society 18(3):27. http://dx.doi.org/10.5751/ES-05072-180327

Willke, H. 1995. Steuerungstheorie. Gustav Fisher Verlag, Stuttgart, Germany.

Yorke, R., B. Walker, C. S. Holling, L. Gunderson, C. Folke, S. Carpenter, and W. Brock. 2002. Toward an integrative synthesis. Pages 419-438 in L. Gunderson and C. S. Holling, editors. Panarchy. Island, Washington, D.C., USA. 


\section{Appendix 1. Methodological considerations}

Table A1.1 Organizations reviewed and documents analysed

\begin{tabular}{|c|c|c|}
\hline Name & Description & Documents \\
\hline $\begin{array}{l}\text { Red Tide Commission } \\
\text { (Comisión Marea Roja) }\end{array}$ & $\begin{array}{l}\text { Ad hoc commission of scientists } \\
\text { appointed by the government to } \\
\text { analyse the origins and } \\
\text { development of the harmful algal } \\
\text { bloom }\end{array}$ & $\begin{array}{ll}\text { - } & \text { First draft Red Tide Commission } \\
\text { - } & \text { Final Report Red Tide Commission } \\
\text { - } & \text { Press release Red Tide Commission }\end{array}$ \\
\hline $\begin{array}{l}\text { Marine Biologists } \\
\text { Association (Asociación } \\
\text { Gremial de Biólogos } \\
\text { Marinos) }\end{array}$ & $\begin{array}{l}\text { Independent association of marine } \\
\text { biologists in Chile }\end{array}$ & - Declaration of Marine Biologists \\
\hline Greenpeace & $\begin{array}{l}\text { Non-governmental environmental } \\
\text { organization }\end{array}$ & $\begin{array}{l}\text { - Report on the social-environmental } \\
\text { crisis in Chiloe }\end{array}$ \\
\hline $\begin{array}{l}\text { Crea Foundation } \\
\text { (Fundación Crea) }\end{array}$ & $\begin{array}{l}\text { Non-governmental environmental } \\
\text { organization }\end{array}$ & - $\quad$ Report on the salmon industry \\
\hline $\begin{array}{l}\text { Association of Artisanal } \\
\text { Fishermen (Asociación } \\
\text { de Pescadores } \\
\text { Artesanales) }\end{array}$ & $\begin{array}{l}\text { Association of Chiloe's sea } \\
\text { workers and fishermen }\end{array}$ & $\begin{array}{l}\text { Declaration of artisanal fishermen } \\
\text { (Propositions for conflict resolution) }\end{array}$ \\
\hline $\begin{array}{l}\text { Sernapesca (National } \\
\text { Fishing Service) }\end{array}$ & $\begin{array}{l}\text { Technical agency of the Chilean } \\
\text { government in charge of the } \\
\text { technical regulation of industrial } \\
\text { and artisanal fishing and related } \\
\text { matters }\end{array}$ & 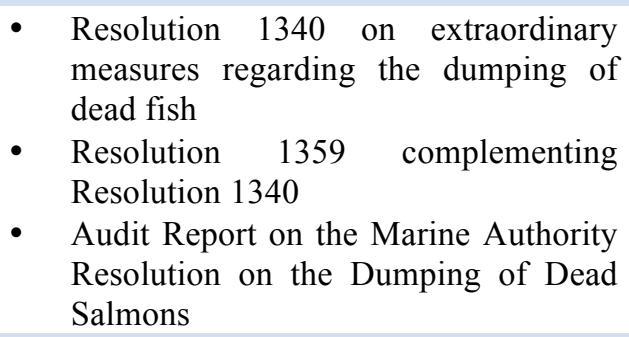 \\
\hline Directemar & $\begin{array}{l}\text { Technical agency of the Chilean } \\
\text { Army in charge of the supervision } \\
\text { of sea affairs and international } \\
\text { regulations. Includes Dirsomar } \\
\text { (security and maritime } \\
\text { operations), Dirinmar (maritime } \\
\text { interests and aquatic environment) } \\
\text { and Shoa (hydrographical and } \\
\text { oceanographic service) }\end{array}$ & 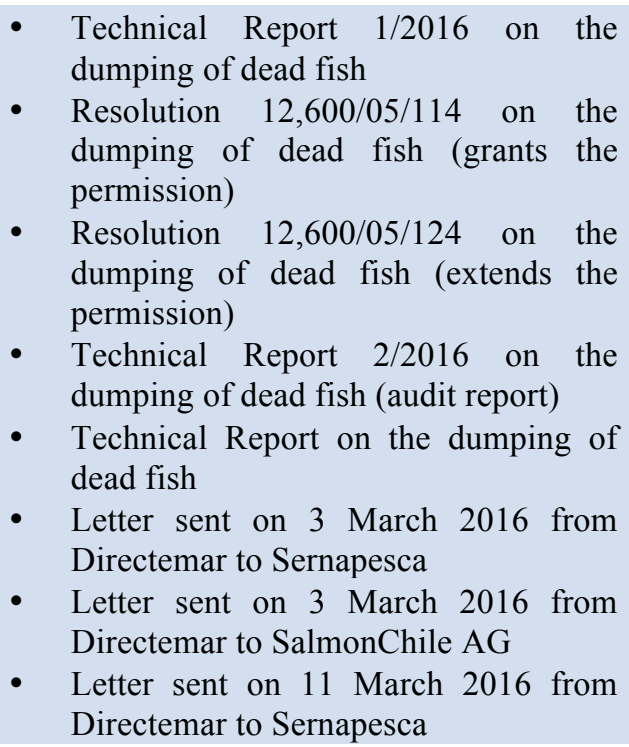 \\
\hline SalmonChile AG & $\begin{array}{l}\text { Association of Chilean salmon } \\
\text { industry }\end{array}$ & $\begin{array}{l}\text { - Technical Report on the dumping } \\
\text { request } \\
\text { Letter 21/2016 sent on } 2 \text { March } 2016 \\
\text { from SalmonChile to Dirinmar } \\
\text { - Letter 22/2016 sent on } 4 \text { March } 2016 \\
\text { from SalmonChile to Directemar } \\
\text { - Letter 23/2016 sent on } 5 \text { March } 2016\end{array}$ \\
\hline
\end{tabular}




\begin{tabular}{lll}
\hline $\begin{array}{l}\text { Ministry of Economy } \\
\text { (Ministerio de Economía) }\end{array}$ & $\begin{array}{l}\text { Ministry of Economy, in charge } \\
\text { of managing the crises through an } \\
\text { ad hoc round table }\end{array}$ & $\begin{array}{l}\text { from SalmonChile to Directemar } \\
\text { Agreement between the Central } \\
\text { Government and Chiloe's fishing } \\
\text { communities } \\
\text { Press release 9 May 2016 }\end{array}$ \\
$\begin{array}{l}\text { Ministry of Health } \\
\text { (Ministerio de Salud) }\end{array}$ & $\begin{array}{l}\text { Ministry of Health, in charge of } \\
\text { declaring ban on fishing }\end{array}$ & $\begin{array}{l}\text { Resolution 484 on the ban on fishing } \\
\text { and shellfish extraction }\end{array}$ \\
$\begin{array}{l}\text { Ministry of the Interior } \\
\text { (Ministerio del Interior) }\end{array}$ & $\begin{array}{l}\text { Ministry of the Interior, in charge } \\
\text { of national, public security. } \\
\text { Active role during the } \\
\text { mobilizations }\end{array}$ & $\begin{array}{l}\text { Decree 499 on the declaration of } \\
\text { Chiloe as catastrophe zone }\end{array}$ \\
\hline
\end{tabular}

\section{Table A1.2 In-depth interviews}

\begin{tabular}{|c|c|c|c|}
\hline & Type of actor & Gender & Type of organisation \\
\hline 1 & Secretary of Planning, Municipality of Quellón & $\mathrm{m}$ & Political organisation 1 \\
\hline 2 & Fishing Department, Municipality of Quellón & $\mathrm{f}$ & Political organisation 2 \\
\hline 3 & $\begin{array}{l}\text { Technician for dumping of dead salmons, Instituto de } \\
\text { Fomento Pesquero (national) }\end{array}$ & $\mathrm{m}$ & Technical organisation \\
\hline 4 & $\begin{array}{l}\text { Head of the Laboratory of Marine Toxins, Universidad } \\
\text { de Chile (national) }\end{array}$ & $\mathrm{m}$ & Scientific organisation 1 \\
\hline 5 & $\begin{array}{l}\text { Head of the Centre for Marine Biotechnology, } \\
\text { Universidad de Santiago de Chile (national) }\end{array}$ & $\mathrm{m}$ & Scientific organisation 2 \\
\hline 6 & $\begin{array}{l}\text { Associate Professor in Oceanography, Universidad de } \\
\text { Concepción (national) }\end{array}$ & $\mathrm{f}$ & Scientific organisation 3 \\
\hline 7 & Centro de Estudios de Chiloé, Castro & $\mathrm{m}$ & Research organisation 1 \\
\hline 8 & Greenpeace Chile Chief of Campaigns (national) & $\mathrm{f}$ & Environmental organisation 1 \\
\hline 9 & Director of Greenpeace Chile (national) & $\mathrm{m}$ & Environmental organisation 2 \\
\hline 10 & $\begin{array}{c}\text { President of the Commerce and Tourism Chamber, } \\
\text { Dalcahue }\end{array}$ & $\mathrm{f}$ & Commerce organisation 1 \\
\hline 11 & $\begin{array}{c}\text { President of the Commerce and Tourism Chamber, } \\
\text { Ancud }\end{array}$ & $\mathrm{m}$ & Commerce organisation 2 \\
\hline 12 & $\begin{array}{c}\text { President of the Commerce and Tourism Chamber, } \\
\text { Castro }\end{array}$ & $\mathrm{f}$ & Commerce organisation 3 \\
\hline 13 & Feminist NGO, Castro & $\mathrm{f}$ & Activist organisation 1 \\
\hline 14 & NGO Defendamos Chiloe, Castro & $\mathrm{f}$ & Activist organisation 2 \\
\hline 15 & NGO Defendamos Chiloe, Castro & $\mathrm{f}$ & Activist organisation 3 \\
\hline 16 & NGO Colectivo Varones Antipatriarcales, Castro & $\mathrm{m}$ & Activist organisation 4 \\
\hline 17 & President of Divers Union, Dalcahue & $\mathrm{m}$ & Fishing organisation 1 \\
\hline 18 & President of artisanal fishing Union 1, Dalcahue & $\mathrm{m}$ & Fishing organisation 2 \\
\hline 19 & Union member artisanal fishing, Quellón & $\mathrm{m}$ & Fishing organisation 3 \\
\hline 20 & Union member artisanal fishing, Quellón & $\mathrm{f}$ & Fishing organisation 4 \\
\hline 21 & President of artisanal fishing Union 2, Dalcahue & $\mathrm{m}$ & Fishing organisation 5 \\
\hline 22 & $\begin{array}{c}\text { Union member artisanal fishing (representing indigenous } \\
\text { communities), Quellón }\end{array}$ & $\mathrm{m}$ & Fishing organisation 6 \\
\hline 23 & Union member artisanal fishing, Quellón & $\mathrm{m}$ & Fishing organisation 7 \\
\hline 24 & Union member artisanal fishing, Puerto Montt & $\mathrm{m}$ & Fishing organisation 8 \\
\hline 25 & $\begin{array}{l}\text { President of the National Federation of Salmon Workers, } \\
\text { Puerto Montt }\end{array}$ & $\mathrm{m}$ & Fishing organisation 9 \\
\hline 26 & $\begin{array}{c}\text { Member of the National Federation of Salmon Workers, } \\
\text { Puerto Montt }\end{array}$ & $\mathrm{m}$ & Fishing organisation 10 \\
\hline 27 & Member of Social Assembly, Castro & $\mathrm{m}$ & Social organisation 1 \\
\hline 28 & $\begin{array}{c}\text { Provincial Federation of Neighbourhood Associations of } \\
\text { Rural Sectors, Ancud }\end{array}$ & $\mathrm{m}$ & Social organisation 2 \\
\hline 29 & President of the Neighbourhood Associations of Rural & $\mathrm{m}$ & Social organisation 3 \\
\hline
\end{tabular}




\begin{tabular}{|c|c|c|c|}
\hline & Sectors, Quellón & & \\
\hline 30 & CEO Pacific Star & $\mathrm{m}$ & Salmon industry 1 \\
\hline 31 & Director of Communications SalmonChile & $\mathrm{m}$ & Salmon industry 2 \\
\hline
\end{tabular}

\section{Semantic analysis of Twitter data}

We used the public timeline API method provided by Twitter to collect information about the non-protected users who have set a custom user icon in real time. In our case, users were placed into four main groups that predominantly relate to four social positions: technical agents (Actors 1), non-governmental organizations (Actors 2), fishermen social organizations (Actors 3), and political authorities (Actors 4). Details of the user, such as IDs, screen name, and date were extracted. We used a Python library called Tweepy to connect to Twitter Streaming API and download the data. The dataset is a random sample of 27,935 tweets (including retweets) captured over the period 2013-2017. This sample includes tweets from 11 unique users (see Table A1.3).

Table A1.3 Actors and Tweeter accounts

\begin{tabular}{llc}
\hline Actors & Twitter accounts & Number of tweets \\
\hline Actors 1: Technical agents (Fishing National & @sernapesca & 9794 \\
Service, Institute for the Promotion of Fishing, & @ifop_periodista \\
Chilean Army, Association of Salmon Farmers) & @Armada_Chile & @SalmonChileAG \\
Actors 2: Non-governmental organizations & @GreenpaceCL & 4781 \\
(Greenpeace, Crea Foundation) & @ fundacioncrea & 3673 \\
Actors 3: Fishing organizations (National & @ConapachChile & \\
Association of Artisanal Fishers, Federation of & @fetrapes & 9687 \\
Fishermen) & & \\
Actors 4: Political authorities (Ministry of Economy, @meconomia & @subpescaCl \\
Subsecretary of Fishing, Intendancy Los Lagos) & @intendencialos1 \\
\hline
\end{tabular}

After the tweets were downloaded, we created the corpus of 27,935 documents (tweets) to conduct the analysis. This analysis was conducted using the open-source $\mathrm{R}$ software environment for statistical computing. Each tweet is treated as a single document. The most common way of organizing the text documents such as Tweeter is to represent them using the Term Document Matrix. The matrix records the frequency of keywords along with the document in which these keywords appear (see Table A1.4).

Table A1.4 Keywords for the selection of Tweets

Original words in Spanish

Crisis, desastre, alga, nocivo, paralización, protesta, floración, verter, vertedero, cambio, climático, ley, pesca, artesanal, muerto, salmón, calentamiento, niño, marea, roja, eutrofización, vertimiento, varazón, molusco, marisco, mariscador, petitorio, sacrificio, deliberado, zona, catástrofe, bono, buzo, mortandad, toxico.

\section{Translation}

Crisis, disaster, alga, harmful, paralyzing, protest, bloom, dump, dumping zone, change, climatic, law, fishing, artisanal, dead, salmon, warming, Niño, tide, red, eutrophication, dumping, stranding, mollusc, shellfish, shell fisherman, request, sacrifice, deliberate, zone, catastrophe, bonus, diver, mortality, toxic. 
In subsequent steps, we removed the punctuation marks, all repeated characters like spaces or repeated vowels, numbers, prepositions and conjunctions from the set of words and URLs from the corpus. Then, to analyse how the actors tweet in relation to the red tide event, we selected only those tweets containing the keywords in Table A1.4. The final corpus for the four groups of actors has 5,104 tweets; it is shown as a time series in Figure A1.1.

Figure A1.1 Time series of actors' utterances 2013-2017
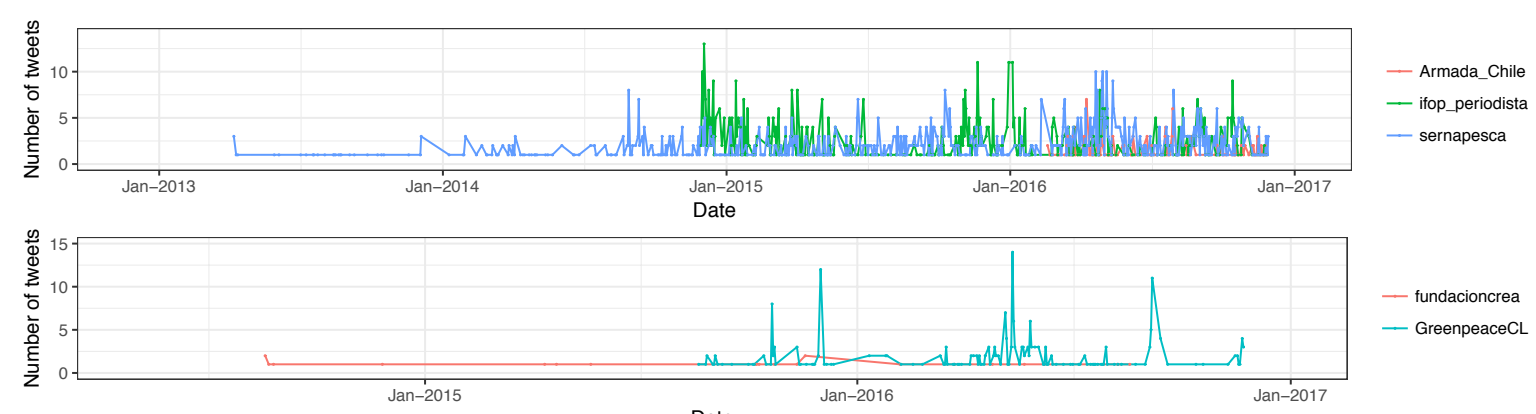

- fundacioncrea

- GreenpeaceCL

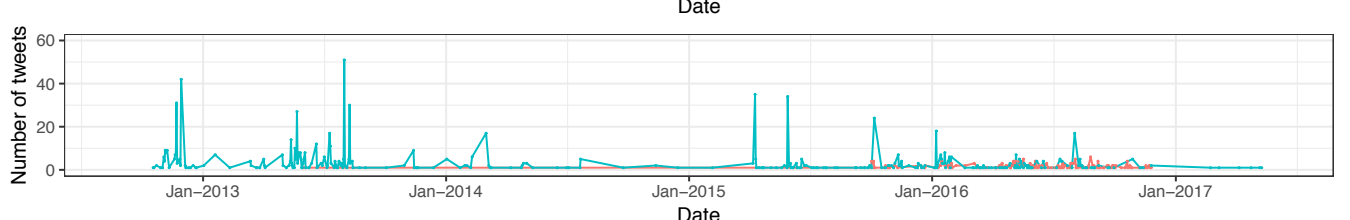

- ConapachChile

— fetrapes

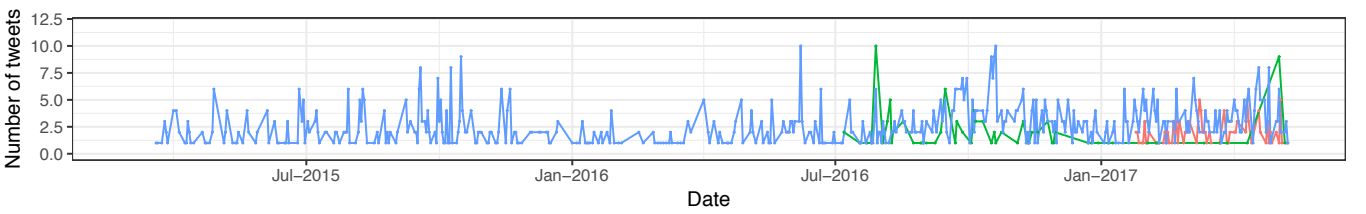

— intendialos 1

- meconomia

- SubpescaCL

\section{Identification of word associations}

In Figures 5, 6 and 7 of the article, we identified word associations by specifying a correlation limit. If two words always appear together then the correlation would be 1 and if they never appear together the correlation would be 0 . Thus, the correlation is a measure of how closely associated the words are in the corpus.

Rgraphviz from the BioConductor repository for R (bioconductor.org) is used to plot the network graph that displays the correlation between chosen words in the corpus. Considering the total amount of words for each period, we choose 60,30 and 50 of the more frequent words as the nodes for the three periods: a) 2013 to February 2016; b) March to May 2016, and c) June 2016 to Jan 2017, respectively. In addition, we considered links between words when they had at least a correlation of 0.01 (links with thicker lines indicate high correlation). 


\section{Appendix 2. Selected materials from in-depth interviews and documents for the first, second, and third controversy}

\section{First controversy: the truth of stranded shellfish}

The first controversy refers to the poisoning of seawaters and the massive stranding of shellfish at Chiloe's seaside. Table A2.1 presents controversial sentences explaining the stranding of shellfish through the 'poisoning of waters' either as a consequence of the pollution produced by the salmon industry or as a natural consequence of harmful algal blooms. For the detail of sources, see Table A1.2.

Table A2.1 Controversial sentences from in-depth interviews on the topic 'poisoning of waters' (including selected material from key documents)

\begin{tabular}{|c|c|c|c|}
\hline \multirow[b]{2}{*}{ Sources } & \multicolumn{2}{|c|}{ Contents understanding the poisoning of waters } & \multirow[b]{2}{*}{ Sources } \\
\hline & $\begin{array}{c}\text { as a consequence of pollution produced } \\
\text { by the salmon industry }\end{array}$ & $\begin{array}{c}\text { as a natural consequence of } \\
\text { harmful algal blooms }\end{array}$ & \\
\hline $\begin{array}{l}\text { Social } \\
\text { organisation } 2\end{array}$ & $\begin{array}{l}\text { You can't go to the beach because it's poisoned. It's as if you } \\
\text { suddenly become blind and deaf [...]. This wasn't the nature; } \\
\text { it was on purpose. }\end{array}$ & $\begin{array}{l}\text { There was an algal bloom. Why? Because algae depend on } \\
\text { water temperatures. Look how much it has rained in the south } \\
\text { lately. Today there is } 50 \% \text { water deficit. }\end{array}$ & $\begin{array}{l}\text { Scientific } \\
\text { organisation } \\
2\end{array}$ \\
\hline $\begin{array}{l}\text { Activist } \\
\text { organisation } 1\end{array}$ & $\begin{array}{l}\text { Coasts are full of polystyrene foam and metallic structures } \\
\text { coming from the salmon industry. }\end{array}$ & $\begin{array}{l}\text { This was the worst toxic outbreak of the paralyzing toxin in } \\
\text { Chile, the largest in Chiloe. And now the next toxic outbreak } \\
\text { will come. }\end{array}$ & $\begin{array}{l}\text { Scientific } \\
\text { organisation } \\
1\end{array}$ \\
\hline $\begin{array}{l}\text { Social } \\
\text { organisation } 1\end{array}$ & $\begin{array}{l}\text { The Chilote sea is highly contaminated; you have to invest a } \\
\text { lot to improve it [...] Pollution comes from many years ago } \\
\text { [...] We saw miles of dead seafood, dead whales, dead fish, } \\
\text { dead birds. We did not have to eat. That is shocking. }\end{array}$ & $\begin{array}{l}\text { These toxins do not appear at any time of the year. This } \\
\text { happens in Chiloe always between February and May. This } \\
\text { time with the ocean tension it was longer, but it also began in } \\
\text { the same months of summer. }\end{array}$ & $\begin{array}{l}\text { Scientific } \\
\text { organisation } \\
1\end{array}$ \\
\hline $\begin{array}{l}\text { Fishing } \\
\text { organisation } 3\end{array}$ & $\begin{array}{l}\text { They have not only polluted the sea by bringing here the red } \\
\text { tide with their ships. They have polluted the sea with } \\
\text { antibiotics, contaminating the native fauna with faeces, } \\
\text { antibiotics, traces of tires and an immense amount of garbage. }\end{array}$ & $\begin{array}{l}\text { We cannot eradicate what is already present in these coasts } \\
\text { and that is precisely the harmful algae that at some point is } \\
\text { going to re-trigger. }\end{array}$ & $\begin{array}{l}\text { Political } \\
\text { organisation } \\
1\end{array}$ \\
\hline $\begin{array}{l}\text { Fishing } \\
\text { organisation } 7\end{array}$ & $\begin{array}{l}\text { We are upset with the overexploitation led by salmon farmers } \\
\text { and with seeing how they throw the dirt at the door of our } \\
\text { house }[\ldots] \text { it is disrespectful towards our people }[\ldots] \text { Today }\end{array}$ & $\begin{array}{l}\text { The salmon died, but what happened? They say, "Hey look, } \\
\text { with the dumping, they fed the catenella". But it has nothing } \\
\text { to do. It was proved that changes in temperature, light }\end{array}$ & $\begin{array}{l}\text { Scientific } \\
\text { organisation } \\
2\end{array}$ \\
\hline
\end{tabular}


we have a tremendous crisis because the salmon industry poisoned the sea and impoverished the culture of our people over years.

Activist

Look what's happening. This is serious; they are throwing

organisation 2 thousands of tons of rotten fish with antibiotics, with acids into the sea. Something horrible is happening.

$\begin{array}{ll}\begin{array}{l}\text { Greenpeace } \\ \text { Report }\end{array} & \begin{array}{l}\text { Salmon in the process of decomposition produce high } \\ \text { amounts of ammonium (NH4), which corresponds to the } \\ \text { nutrient and 'favourite' food of the microalgae, particularly } \\ \text { dinoflagellates (which can generate toxic bloom or 'red tide'). } \\ \text { The dumping, consequently, acted as a fertilizer for the algal } \\ \text { bloom, stimulating the development and growth of these } \\ \text { microalgae. }\end{array} \\ \text { Crea } & \begin{array}{l}\text { The high density of salmon in farmer cages, the dumping of } \\ \text { pellets into the sea, the organic waste from salmon and the }\end{array} \\ \text { Reundation } & \begin{array}{l}\text { large quantity of antibiotics supplied to them, generates an } \\ \text { environmental imbalance that affects not only living systems, } \\ \text { but also the local economy based on the small-scale } \\ \text { exploitation of seafood. }\end{array}\end{array}$

conditions, triggered everything.

The toxic algae (Alexandrium catenella) are endemic to that Scientific area. It has always been there, since the sixties. It began in the region of Magallanes. The problem is that it has expanded, but 3 they always have these algal blooms.

Since that time [1972], and over the last decades, cells and

Final Report high concentrations of the toxin known as Paralytic Shellfish

Red Tide

Poison (PSP) have spread along the coast of fjords and channels of southern Chile, from the southern end of

Commission

Magallanes $\left(55^{\circ} \mathrm{S}\right)$ to the south-central coast of the island of Chiloé $\left(41^{\circ} \mathrm{S}\right)$.

We can mention the following scientifically backed factors

Declaration that affect and promote the algal bloom: global warming, acidification, an extreme El Niño phenomenon and eutrophication of inland waters [...] The only thing clear with this microalgal bloom is that it is NOT a local scale phenomenon and less of a local origin. 


\section{Second controversy: the dumping of dead salmons}

The second controversy refers to the causes of the red tide. Table A2.2 presents controversial sentences explaining the red tide either as a consequence of the dumping of dead salmons in Chiloe's offshore or as a natural consequence of climatic conditions. For the detail of sources see Table A1.2.

\section{Table A2.2 Controversial sentences from in-depth interviews on the topic 'red tide' (including selected material from key} documents)

\begin{tabular}{|c|c|c|c|}
\hline \multirow[b]{2}{*}{ Sources } & \multicolumn{2}{|c|}{ Contents understanding the red tide } & \multirow[b]{2}{*}{ Sources } \\
\hline & as a consequence of the dumping of dead salmons & as a natural consequence of climatic conditions & \\
\hline $\begin{array}{l}\text { Social } \\
\text { organisation } 2\end{array}$ & $\begin{array}{l}\text { The worst thing they did was to feed the crisis by dumping the } \\
\text { salmons near to Ancud. It was not } 20 \text { miles away, as they said, } \\
\text { but much closer. That caused another outbreak of the red tide. }\end{array}$ & $\begin{array}{l}\text { You realize it has to do with global warming. The salmon } \\
\text { have nothing to do with this. }\end{array}$ & $\begin{array}{l}\text { Scientific } \\
\text { organisation } \\
2\end{array}$ \\
\hline $\begin{array}{l}\text { Activist } \\
\text { organisation } 2\end{array}$ & $\begin{array}{l}\text { I do not think there was as much red tide as they said, because } \\
\text { it started after the dumping. I think that someone said: "Ah, } \\
\text { let's say there is a red tide, so people do not eat as much sea } \\
\text { food because we dumped the salmon into the sea". }\end{array}$ & $\begin{array}{l}\text { The red tide will always be here. And with changes of sea } \\
\text { temperature, there will always be red tide. }\end{array}$ & $\begin{array}{l}\text { Political } \\
\text { organisation } \\
2\end{array}$ \\
\hline $\begin{array}{l}\text { Commerce } \\
\text { organisation } 3\end{array}$ & $\begin{array}{l}\text { Over time it was understood that what happened was not red } \\
\text { tide, but the infection of the sea by the dumping of rotten fish } \\
\text { authorized by Sernapesca, out there in Ancud. }\end{array}$ & $\begin{array}{l}\text { The dumping of dead salmon had no responsibility for the } \\
\text { algal bloom. }\end{array}$ & $\begin{array}{l}\text { Scientific } \\
\text { organisation } \\
3\end{array}$ \\
\hline $\begin{array}{l}\text { Fishing } \\
\text { organisation } 3\end{array}$ & $\begin{array}{l}\text { Welboats brought the red tide to our region. It was there, } \\
\text { present; only the food was lacking. It had luminosity, } \\
\text { temperature; it had the entire atmosphere that would make the } \\
\text { red tide burst. It lacked the food and the food was the salmon } \\
\text { with the chemicals, with all the things they injected into the } \\
\text { salmon. They threw them into the Pacific Ocean and fed the } \\
\text { red tide. }\end{array}$ & $\begin{array}{l}\text { The problem is the people and their cultivation techniques. } \\
\text { For example, if a person comes from the south and brings } \\
\text { water weights in the boat, the water comes with sediments that } \\
\text { precipitate in that place and are dragged by the current. That is } \\
\text { why sediment was found in the sea of Chiloe. How does it } \\
\text { happen? Under particular environmental conditions the } \\
\text { harmful algae proliferate and generate the red tide. }\end{array}$ & $\begin{array}{l}\text { Political } \\
\text { organisation } \\
1\end{array}$ \\
\hline $\begin{array}{l}\text { Fishing } \\
\text { organisation } 4\end{array}$ & $\begin{array}{l}\text { We had in some sectors up to } 1,800 \text { micrograms of toxin per } \\
\text { shellfish. It was the authorized dumping of millions of tons of } \\
\text { products in the water, without precaution and with chemicals, } \\
\text { what overheated the waters. }\end{array}$ & $\begin{array}{l}\text { The dead salmon could not reach the coast. Algae had already } \\
\text { bloomed at seaside before the dumping. Do you understand } \\
\text { me? There is no causal relationship. }\end{array}$ & $\begin{array}{l}\text { Scientific } \\
\text { organisation } \\
3\end{array}$ \\
\hline
\end{tabular}




\begin{tabular}{|c|c|c|c|}
\hline $\begin{array}{l}\text { Fishing } \\
\text { organisation } 2\end{array}$ & $\begin{array}{l}\text { The Seremi [regional Ministry] of Fishing, the Seremi of } \\
\text { Health, the National Director of Sernapesca, and the National } \\
\text { Director of the Subsecretary of Fishing should be denounced. } \\
\text { They ordered the fish to be dumped into the sea. If they had } \\
\text { observed the dumping regulations, nothing would have } \\
\text { happened. }\end{array}$ & $\begin{array}{l}\text { You need to have good practices, but they just sometimes } \\
\text { make mistakes. That makes algae spreading to other places. }\end{array}$ & $\begin{array}{l}\text { Political } \\
\text { organisation } \\
2\end{array}$ \\
\hline $\begin{array}{l}\text { Greenpeace } \\
\text { Report }\end{array}$ & $\begin{array}{l}\text { When analysing the superficial speed of the sea, it is possible } \\
\text { to observe that the displacement from the dumping point was } \\
\text { toward the south and not towards the north. Therefore, the } \\
\text { circulation pattern of the spill and residence times were } \\
\text { affected, making them available as food for the microalgae } \\
\text { already present [...] In the outer sea of Chiloe the bloom is } 5 \\
\text { times more intense than in the interior sea. More than } 30 \\
\text { different types of microalgae were found, } 5 \text { of them } \\
\text { potentially toxic, such as Alexandrium catenella. }\end{array}$ & $\begin{array}{l}\text { The wind conditions observed in March-April } 2016 \text { and the } \\
\text { expected circulation pattern, further aligned with the sea } \\
\text { surface temperature patterns and geostrophic currents derived } \\
\text { from satellite measurements for the same period, suggest that } \\
\text { the transport of water and suspended material during and after } \\
\text { the dumping of salmon occurred mostly from east to west (out } \\
\text { to sea) and from south to north. Therefore, it did not come to } \\
\text { the island of Chiloe. }\end{array}$ & $\begin{array}{l}\text { Final Report } \\
\text { Red Tide } \\
\text { Commission }\end{array}$ \\
\hline $\begin{array}{l}\text { Crea } \\
\text { Foundation } \\
\text { Report }\end{array}$ & $\begin{array}{l}\text { The environmental pressure caused by growing salmon } \\
\text { densities without the necessary sanitary considerations is } \\
\text { related with faecal and unconsumed food being artificially } \\
\text { incorporated into the environment. Carbon and phosphorus } \\
\text { accumulate under cages, while nitrogen is dissolved in the } \\
\text { water column. These non-natural contributions date back more } \\
\text { than } 20 \text { years. This is why the scenario of eutrophication and } \\
\text { loss of oxygen in the coastal waters of Chiloe is undeniable. }\end{array}$ & $\begin{array}{l}\text { The evidence gathered from climatic, meteorological, } \\
\text { oceanographic, and biological information analysed by this } \\
\text { committee, obtained from both national and international } \\
\text { public sources and from the cruise, allows us to conclude that } \\
\text { the dumping of salmon at } 75 \text { nautical miles west of the coast } \\
\text { of Chiloe, has no direct relationship with the harmful algal } \\
\text { blooms in the region. }\end{array}$ & $\begin{array}{l}\text { Press release } \\
\text { Red Tide } \\
\text { Commission }\end{array}$ \\
\hline
\end{tabular}




\section{Third controversy: the meaning of mobilizations}

The third controversy refers to the meaning of mobilizations. Table A2.3 presents controversial sentences explaining mobilizations either as a consequence of historical disappointments (longstanding social problem) or as a particular problem of unemployment (short-terms problem). For the detail of sources see Table A1.2.

\section{Table A2.3 Controversial sentences from in-depth interviews on the topic 'mobilizations' (including selected material from key} documents)

\begin{tabular}{|c|c|c|c|}
\hline \multirow[b]{2}{*}{ Sources } & \multicolumn{2}{|c|}{ Contents understanding mobilizations } & \multirow[b]{2}{*}{ Sources } \\
\hline & as a longstanding social problem & as a short-term economic problem & \\
\hline $\begin{array}{l}\text { Fishing } \\
\text { organisation } \\
10\end{array}$ & $\begin{array}{l}\text { Of all the historical promises that have been made to Chiloe, } \\
\text { concerning improvements in education, health, and social } \\
\text { issues, little has been done so far. Too much promises from } \\
\text { governments but very few concrete things to improve living } \\
\text { standards of a community that has been hit by so many } \\
\text { phenomena, both natural and social. }\end{array}$ & $\begin{array}{l}\text { People in public positions, who have to do with the decision- } \\
\text { making, are always pointed out as responsible. And it is rather } \\
\text { the system bureaucracy that delays everything. When the } \\
\text { problem occurs, the person needs to be given a relief solution. }\end{array}$ & $\begin{array}{l}\text { Political } \\
\text { organisation } \\
1\end{array}$ \\
\hline $\begin{array}{l}\text { Social } \\
\text { organisation } 2\end{array}$ & $\begin{array}{l}\text { Chiloe has never been considered with a look that respects its } \\
\text { worldview and particular history. It is treated exactly in the } \\
\text { same way as any other territory in the country. This is } \\
\text { reflected in health, housing, and connectivity policies. That is } \\
\text { to say, the same scheme of development is applied. The local } \\
\text { viewpoint is not considered. }\end{array}$ & $\begin{array}{l}\text { The downside is that they are accustomed [Chiloe inhabitants] } \\
\text { to going out on the streets when there is a problem, and this is } \\
\text { not the idea. The idea is to dialogue first, and see if there can } \\
\text { be a solution. }\end{array}$ & $\begin{array}{l}\text { Political } \\
\text { organisation } \\
2\end{array}$ \\
\hline $\begin{array}{l}\text { Social } \\
\text { organisation } 1\end{array}$ & $\begin{array}{l}\text { There is a major problem. And nothing has been done [by the } \\
\text { government] in the last thirty, forty years. }\end{array}$ & $\begin{array}{l}\text { Efforts were made to deliver boxes with food and [to transfer] } \\
\text { the bonus given by the government. I think these things are } \\
\text { solvable. But when it comes to environmental issues, pollution } \\
\text { and the like, I think things are more difficult to solve. }\end{array}$ & $\begin{array}{l}\text { Political } \\
\text { organisation } \\
2\end{array}$ \\
\hline $\begin{array}{l}\text { Commerce } \\
\text { organisation } 2\end{array}$ & $\begin{array}{l}\text { If one analyses those } 17 \text { days, what did fishermen get? } \\
\text { Nothing but a bonus. And when I say nothing, it's nothing. I } \\
\text { think bonuses are not the solution. It is like giving 'gifts'. It } \\
\text { has no impact because the 'gift' is gone after three or six } \\
\text { months. }\end{array}$ & $\begin{array}{l}\text { We put into place the contingency plan with the government: } \\
\text { the bonuses. We take a heavy toll by employing many people } \\
\text { through programs and direct projects. Three hundred million } \\
\text { pesos were executed for the employment of three hundred } \\
\text { people. }\end{array}$ & $\begin{array}{l}\text { Political } \\
\text { organisation } \\
1\end{array}$ \\
\hline Social & Leaders of Ancud are not able to agree with the leaders of & We are doing roundtables with the health sector to be able to & Fishing \\
\hline
\end{tabular}



organisation 1 Quellon, and much less with those of Castro. Finally, these groups are articulated with their political sectors, with their traditional logics, and negotiate demands individually. If one looks at the demands of negotiating groups, they are highly transversal, but it is impossible for them to agree upon the most relevant demands of the Chiloe archipelago as a whole. Instead, the particularities of more powerful groups gain significance, that is, little relevant issues that have nothing to do with the real problems.

Fishing

We continue at the roundtable. In all the meetings the same

organisation 7 thing is repeated: the Chilean State has not fulfilled the work

[...] The [State] did it well: it divided the fishermen's

movement, it separated them into little groups, it negotiated independently with each sector. It gave less to some and more to others. The State did the job cleverly.

Declaration of The harmful algal bloom requires serious and responsible artisanal

fishermen courses of actions from the government, so that it takes into account that we are dealing with a catastrophic mega-event with long-term social and economic effects. apply health regulations to other companies and also to raise awareness about the control of companies and ships that can bring pollution to Chiloe.

The roundtable continues to work until today, but in a more relaxed way. In that sense, we did not fall asleep. Each one makes his/her efforts to make the roundtable work. Things are Fishing going relatively well in that regard.

We as a government have opened the dialogue. We have tried to find agreements on this matter but we have to think about those affected people who have no income [...] The bonus is a Ministry of concrete announcement with a payment procedure and potential beneficiaries. We hope it will be paid in the coming days. 